\title{
Influence of Heat Stress, Variations in Soil Type, and Soil Amendment on the Growth of Three Drought-Tolerant Maize Varieties
}

\author{
Uchechukwu Paschal Chukwudi ${ }^{1,2, *(\mathbb{D})}$, Funso Raphael Kutu ${ }^{3}$ iD and Sydney Mavengahama ${ }^{1}$ \\ 1 Food Security and Safety Niche Area, Faculty of Natural and Agricultural Sciences, School of Agricultural \\ Sciences, North-West University, Mmabatho 2745, South Africa; sydney.mavengahama@nwu.ac.za \\ 2 Department of Crop Science, Faculty of Agriculture, University of Nigeria, Nsukka 410002, Nigeria \\ 3 School of Agricultural Sciences, University of Mpumalanga, Mbombela 1200, South Africa; \\ funso.kutu@ump.ac.za \\ * Correspondence: uchechukwu.chukwudi@unn.edu.ng
}

Citation: Chukwudi, U.P.; Kutu, F.R.; Mavengahama, S. Influence of Heat Stress, Variations in Soil Type, and Soil Amendment on the Growth of Three Drought-Tolerant Maize Varieties. Agronomy 2021, 11, 1485. https://doi.org/10.3390/ agronomy 11081485

Academic Editor: Yong-Bao Pan

Received: 4 June 2021

Accepted: 17 July 2021

Published: 27 July 2021

Publisher's Note: MDPI stays neutral with regard to jurisdictional claims in published maps and institutional affiliations.

Copyright: (c) 2021 by the authors. Licensee MDPI, Basel, Switzerland. This article is an open access article distributed under the terms and conditions of the Creative Commons Attribution (CC BY) license (https:// creativecommons.org/licenses/by/ $4.0 /)$.

\begin{abstract}
Food security in sub-Saharan Africa is threatened by the increasing incidence of heat stress. Therefore, ameliorating heat stress influence in plants is vital for sustainable crop production. A $2 \times 3 \times 3 \times 2$ factorial experiment fitted into a completely randomized design with four replications was performed. The factors were heat stress, maize variety, soil amendment, and soil type. The results showed that heat stress exerted a depressive effect on maize growth and yield attributes. It reduced the leaf chlorophyll content, leaf area, plant height, stem diameter, dry biomass yield, and harvest index by 35\%,36\%, 41\%,59\%, and 78\%, respectively. Sandy clay loam soil provided a better maize growth condition than loamy sand soil. Organic manure soil amendment improved maize growth attributes over the mineral fertilizer in the non-heat-stress environment and ameliorated the negative impact of heat stress in the heat-stress environment. The ranking of the attributes identified leaf area, dry biomass yield, stem diameter, and plant height as the most discriminating and representative attributes. These attributes should be considered in maize development projects for heat-stress prone areas. Selection of appropriate maize variety and accompanying soil amendment should be integrated into food security strategy as they influenced maize growth and yield under (non-)heat-stress conditions.
\end{abstract}

Keywords: climate change; drought-tolerant maize; food security; growth; sustainability; Zea mays L.

\section{Introduction}

Globally, maize (Zea mays L.) is the third most important cereal crop based on the harvested area [1]. It is the most important cereal crop in South Africa [2] and represented the largest contributor to the gross value of field crops in South Africa from 2011/2012 to the 2015/2016 seasons [3]. South Africa is the second-largest maize producer in subSaharan Africa [4] after Nigeria. Maize is a crop that plays key roles in many household diets, poverty reduction, food security, and animal feed [5].

South Africa has a semi-arid climate that has experienced significant changes in rainfall intensity and minimum and maximum temperatures in recent years [6-8]. Jury [6] reported that the climate of South Africa has warmed significantly by over $0.02{ }^{\circ} \mathrm{C} \cdot \mathrm{yr}^{-1}$ from 1980 to 2014. An increase in global extreme weather events, including rising temperature, was reported [7,9-11]. The potential for high-temperature incidences to worsen in the future was also reported [12], thus exposing plants to heat stress with a threat to current and future global maize production [13-15].

Temperature is one of the major environmental factors that control the rate of growth, development, and yield of crops [16]. Extreme weather events adversely affect several physiological processes of plants, resulting in yield losses [4]. The rates of biomass production, crop growth rate, dry matter partitioning, and harvest index in maize were reportedly 
impaired under heat stress [17]. Maize is vulnerable to heat stress during the reproductive stage [18-20]. Assessing the effect of heat stress on maize growth and yield has gained global relevance [21,22] due to its negative impact on the livelihood of many smallholder households, agricultural production, and, in particular, food security.

Globally, large areas under maize cultivation will be reduced due to heat and drought stress, with Africa losing 7-11\% of its maize cultivation land by 2050 [1]. A similar reduction in maize cultivated land was also projected for South Africa due to future climatic changes [23]. Mangani, Tesfamariam, Engelbrecht, Bellocchi, Hassen, and Mangani [4] envisaged a threat to South Africa's maize production capacity in the future due to the increased frequency and severity of extreme weather events. The situation will be exacerbated by wind and water erosions, as well as the depletion of organic matter and nutrients in soils across the major maize production regions in South Africa [24].

Although maize yield had increased recently due to the use of improved varieties, there is uncertainty regarding the sustainability of maize production, with the continuous loss of arable land to soil degradation [24]. An understanding of the relationship between climate stress, management, and soil type is critical to sustainable crop production [25]. Cultivation of marginal lands accompanied by poor management further exacerbates the problem of food insecurity [26]. Proper amendment of marginal soils, as well as the planting of adapted variety, can help mitigate the negative effects of extreme climatic events and ensure food security among smallholder farmers.

Several studies have shown the positive effects of organic soil amendments on crop productivity and restoration of degraded soils [27-30]. However, the adoption of organic manure as a soil amendment is low among farmers in South Africa [31]. The paucity of local scientific trials evaluating the current and alternative agronomic management practices on maize is among the limitations to the adoption of more sustainable management approaches [32].

Globally, information on the influence of extreme climate events is needed by agricultural policymakers to plan for the coming decades, when the frequency and intensity of extreme weather events are expected to increase [4]. Studies on the impact of heat stress on maize production in sub-Saharan Africa are mostly limited to large scale simulation studies, where systematic errors from collinearity between the predictor variables limit the application of such studies [33]. Practical trials promote the adoption of mitigation strategies by farmers.

South Africa's North West Province climate is one of the most vulnerable climates in Southern Africa [9]. Its contribution to the national maize production area decreased from $28.5 \%$ in 1994 to $17.3 \%$ in 2015 due to climate events and low yield [34]. Regional responses to climate change and the attendant effect on maize production depend on its biophysical resources, management, and other factors; thus, studies at finer spatial scales are needed to resolve local hot spots within regions [8,35]. The objective of this study was to evaluate the influence of heat stress and variations in soil type and soil amendment on the growth and biomass yield of three maize cultivars in the semi-arid region of South Africa.

\section{Materials and Methods}

\subsection{Description of the Study Site}

The study was conducted in the North West Province of South Africa. The province is classified as a semi-arid region with average daily minimum and maximum temperatures of 0.9 and $32{ }^{\circ} \mathrm{C}$, respectively, with approximately $300-600 \mathrm{~mm}$ of rainfall annually [36]. The experiments were performed in a greenhouse and a net shade house at the NorthWest University Experimental Farm. The repeated experiment was conducted in the 2018/2019 and 2019/2020 summer planting seasons. Morning (07.00-08.00 a.m.) and midday (12.00-13.00 p.m.) daily temperature readings in the greenhouse and net shade house were recorded during the study period. The source of the maize seeds used in this study was from the Agricultural Research Council Grain Crops, Potchefstroom. Surface soils $(0-20 \mathrm{~cm}$ depths $)$ were from fallow fields in Molelwane $(-25.7902166,25.61879223 .5 \mathrm{mi})$ 
and Tlapeng $(-25.7297143,25.432456113 \mathrm{mi})$, both in the North West Province, South Africa.

Soil and poultry manure samples were analysed for chemical composition (Table 1) before the commencement of the greenhouse experiments following standard procedures. The Bouyoucos hydrometer method [37] was used to determine the soil texture. The total $\mathrm{N}$ was determined using the micro-Kjeldahl digestion procedure [38], while the organic carbon was determined by a modified Walkley and Black procedure, as described by Nelson and Sommers [39]. Available phosphorus was measured following the Bray-1 method [40]. Exchangeable bases (calcium, magnesium, potassium, and sodium) content in the soil were determined in $1.0 \mathrm{~N}$ ammonium acetate $\left(\mathrm{NH}_{4} \mathrm{OAc}\right.$ ) extract, and the exchangeable acidity (hydrogen and aluminium) was determined in $1.0 \mathrm{~N} \mathrm{KCl}$ extract [41]. The poultry manure analyses showed that based on $\mathrm{g} / 100 \mathrm{~g}$, it contained $4.12 \% \mathrm{~N}, 1.45 \% \mathrm{P}, 1.78 \% \mathrm{~K}, 8.18 \% \mathrm{Ca}$, $1.04 \% \mathrm{Mg}$, and $0.41 \% \mathrm{Na}$.

Table 1. The physical and chemical properties of the soil samples.

\begin{tabular}{|c|c|c|}
\hline & $\begin{array}{l}\text { Molelwane Soil } \\
\text { (Hutton Form) }\end{array}$ & $\begin{array}{c}\text { Tlapeng Soil } \\
\text { (Arcadia Form) }\end{array}$ \\
\hline \multicolumn{3}{|l|}{ Particle size distribution } \\
\hline Sand $\%$ & 82 & 64 \\
\hline Silt $\%$ & 4 & 8 \\
\hline Clay\% & 14 & 28 \\
\hline Textural class & Loamy sandy & Sandy clay loam \\
\hline \multicolumn{3}{|l|}{ Chemical properties } \\
\hline $\mathrm{pH}(\mathrm{KCl}) 1: 2.5$ & 4.98 & 5.83 \\
\hline P (Bray1) $\left(\mathrm{mg} \mathrm{kg}^{-1}\right)$ & 11 & 2 \\
\hline $\mathrm{K}\left(\mathrm{mg} \mathrm{kg}^{-1}\right)$ & 290 & 138 \\
\hline $\mathrm{Ca}\left(\mathrm{mg} \mathrm{kg}^{-1}\right)$ & 390 & 2000 \\
\hline $\operatorname{Mg}\left(\mathrm{mg} \mathrm{kg}^{-1}\right)$ & 163 & 1310 \\
\hline $\mathrm{Na}\left(\mathrm{mg} \mathrm{kg}^{-1}\right)$ & 5 & 215 \\
\hline Total N (mg kg $\left.{ }^{-1}\right)$ & 376 & 616 \\
\hline$\% \mathrm{C}$ & 0.37 & 0.76 \\
\hline S-value & 4 & 22 \\
\hline $\mathrm{Ca} \%$ & 48 & 45.2 \\
\hline $\mathrm{Mg} \%$ & 33.2 & 49 \\
\hline $\mathrm{K} \%$ & 18.3 & 1.6 \\
\hline $\mathrm{Na} \%$ & 0.5 & 4.2 \\
\hline Ext. acidity $\left(\mathrm{cmol} \mathrm{kg}^{-1}\right)$ & 0.04 & 0.036 \\
\hline
\end{tabular}

\subsection{Treatments, Experimental Design, and Cultural Practices}

The experimental design was a $2 \times 3 \times 3 \times 2$ factorial in a completely randomized design with four replications. The factors were two soil types, three soil amendments, three maize varieties, and two contrasting growth environments. The growth environments differ in temperature with the heat-stress (HS) environment provided by the plastic greenhouse, while the net shade house represented a non-heat-stress (NHS) environment. Morning and midday temperatures in both environments were obtained throughout the study. The two soils from Molelwane and Tlapeng town had different textural characteristics, namely loamy sand (LS) and sandy clay loam (SCL), respectively. Molelwane and Tlapeng soils are classified as Hutton and Arcadia forms, respectively, according to the South Africa soil classification system [42]. The soil amendment comprised (i) application of sole poultry manure (PM), (ii) application of sole mineral fertilizers (MF), and (iii) complementary (50:50) application of poultry manure and mineral fertilizer (MPM). The mineral fertilizers comprised a mixture of NPK (13:7:10 [30] + 0.5\% Zn +5\% S + 3\% Ca) applied at planting and lime ammonium nitrate $(28 \% \mathrm{~N})$ applied as topdressing, while the poultry manure came from the mature layer birds. The application of each of the soil amendments was at a rate of $180 \mathrm{~kg} \mathrm{~N} \mathrm{ha}^{-1}$. The maize varieties comprised three-way Water Efficient Maize for Africa hybrids: WE3128, WE5323, and an open-pollinated variety, ZM1523. The three 
maize varieties were drought-tolerant with a medium maturity period of 117-120 days. All the factors were combined to generate 36 treatment interactions. However, only the interaction of heat stress, maize variety, and soil amendment was discussed.

Surface soils were excavated, air-dried, sieved, and homogenized with $12 \mathrm{~kg}$ weighed into each plastic planting pot $(30 \mathrm{~cm}$ top $\times 28 \mathrm{~cm}$ height $\times 21 \mathrm{~cm}$ base) containing perforation at the base to allow for proper drainage. The $12 \mathrm{~kg}$ weighed soil and the organic amendments were thoroughly and separately mixed on a polyethene sheet and thereafter transferred into each pot based on the treatment. The pots were well-irrigated to approximately $80 \%$ field capacity and allowed to stand for two weeks for mineralization of the poultry manure before the sowing of the maize seeds. Three maize seeds were sown per pot, but the seedlings were thinned to one per pot at 2 weeks after planting (WAP). The mineral fertilizer rates of 180 and $90 \mathrm{~kg} \mathrm{~N} \mathrm{ha}^{-1}$ for MF and MPM, respectively, were applied in a split dosage, with 50\% applied first at planting using NPK fertilizer and the remaining $50 \%$ supplied using lime ammonium nitrate $(28 \% \mathrm{~N})$ at $7 \mathrm{WAP}$. Weeds were manually removed, and the pots were well-irrigated.

\subsection{Measurement of Plant Response Attributes}

Data were collected from four plants per treatment interaction. Plant height $(\mathrm{cm})$ was measured with a $5 \mathrm{~m}$ steel measuring tape from the soil surface to the tip of the last leaf. Measurements of the leaf length $(\mathrm{cm})$ and leaf width $(\mathrm{cm})$ were performed using a measuring tape from the leaf base on maize stalk to the tip and at the widest part of the leaf for length and width, respectively. The product of leaf length and width was multiplied by a constant of 0.75 , as described by Mokhtarpour et al. [43], to obtain the leaf area $\left(\mathrm{cm}^{2}\right)$. A portable chlorophyll content meter (CCM-200 plus, Opti-Sciences, Hudson, USA) was used to measure the leaf chlorophyll content (CCI), while the number of leaves was counted and recorded. Measurement of the plant stem diameter $(\mathrm{mm})$ entailed the use of a digital Vernier calliper (153-006-11, ACCUD Austria). The growth traits were measured at 4,7 , and $10 \mathrm{WAP}$, corresponding to early vegetative, mid-vegetative, and early reproductive phases. At the onset of the reproductive phase, plants were monitored to determine the number of days until tassel and silk appearances. The number of days until tassel appearance was subtracted from the number of days until silk appearance to obtain the tassel silk interval (TSI).

Measurement of the final plant height was at $20 \mathrm{WAP}$. Thereafter, the plants were harvested with sharp secateurs. The harvested cobs were air-dried under shade until $12 \%$ moisture content was attained, while the shoots were oven-dried at $65^{\circ} \mathrm{C}$ to constant weight for determination of dry biomass yield (DBY). The grain weight and husk weight were recorded after shelling for harvest index determination. Harvest index was calculated as:

$$
\text { Harvest Index }(\%)=\frac{\text { Grain weight }(\mathrm{g})}{\text { Biological weight }(\mathrm{g})} \times \frac{100}{1}
$$

where biological weight was the summation of dry biomass weight and cob weight.

The maximum/minimum temperatures, rainfall, and relative humidity data outside the growth structures for the two planting seasons were obtained from the South African Weather Services.

\subsection{Data Analysis}

The weather data from the South African Weather Service for the two planting seasons were compared using a $t$-test. The daily temperature values in the two growth structures were summarized on a weekly basis and subjected to a T-test while analysis of variance (ANOVA) was performed on the collected growth and yield data, following the procedure for factorial in completely randomized design using GenStat Software (VSN Int. Ltd., Hemel Hempstead, UK). Protected Fisher's least significant difference test was used as a post hoc test for mean separation at $p \leq 0.05$. Line graphs were plotted using a Microsoft Excel spreadsheet to show the trend of measured attributes. GGEbiplot software [44] was 
used to rank the treatment interactions and the studied attributes. The difference in the maize attributes due to the heat stress effect was calculated as:

$$
\text { Difference }(\%)=\frac{\mathrm{Ta}-\mathrm{Tb}}{\mathrm{Tb}} \times \frac{100}{1}
$$

where Ta was the mean of attribute $X$ in the non-heat-stress environment, and $\mathrm{Tb}$ was the mean of the same attribute in the heat-stress environment.

\section{Results}

\subsection{Temperature Variations between Growth Structures}

The pairwise comparison of temperatures in the HS and NHS environments for the two summer planting seasons (2018/2019 vs. 2019/2020) was presented in Table 2. Comparison of Season 1 midday temperatures in the HS environment and the NHS environment revealed a significant $(p \leq 0.001)$ higher temperature in the HS environment. Similarly, the midday temperatures in the HS environment was significantly $(p \leq 0.001)$ higher than the NHS environment for Season 2.

Table 2. Season and environment pairwise comparison of temperature.

\begin{tabular}{|c|c|c|c|c|c|c|}
\hline Treatment & Size & Mean & $\begin{array}{l}\text { Standard } \\
\text { Deviation }\end{array}$ & Test Statistic & $\begin{array}{l}\text { Degree of } \\
\text { Freedom }\end{array}$ & Probability \\
\hline Season 1-Midday-HS & 20 & 31.96 & 4.181 & 4.01 & 38 & $<0.001$ \\
\hline Season 1-Midday-NHS & 20 & 27.12 & 3.400 & & & \\
\hline Season 2-Midday-HS & 19 & 37.46 & 3.164 & 9.38 & 36 & $<0.001$ \\
\hline Season 2-Midday-NHS & 19 & 29.51 & 1.984 & & & \\
\hline Season 2-Midday-HS & 19 & 37.46 & 3.164 & 4.62 & 37 & $<0.001$ \\
\hline Season 1-Midday-HS & 20 & 31.96 & 4.181 & & & \\
\hline Season 2-Midday-NHS & 19 & 29.51 & 1.984 & 2.69 & 37 & 0.011 \\
\hline Season 1-Midday-NHS & 20 & 27.12 & 3.400 & & & \\
\hline Season 2-Morning-NHS & 19 & 24.32 & 2.817 & 2.90 & 37 & 0.006 \\
\hline Season 1-Morning-NHS & 20 & 21.20 & 3.807 & & & \\
\hline Season 2-Morning-HS & 19 & 28.18 & 3.100 & 4.23 & 37 & $<0.001$ \\
\hline Season 1-Morning-HS & 20 & 23.14 & 4.222 & & & \\
\hline Season 1-Morning-HS & 20 & 23.14 & 4.222 & 1.53 & 38 & 0.135 \\
\hline Season 1-Morning-NHS & 20 & 21.20 & 3.807 & & & \\
\hline Season 2-Morning-HS & 19 & 28.18 & 3.100 & 4.02 & 36 & $<0.001$ \\
\hline Season 2-Morning-NHS & 19 & 24.32 & 2.817 & & & \\
\hline
\end{tabular}

Comparing the midday temperature in the HS environment between Season 1 and Season 2 showed a significantly $(p \leq 0.001)$ higher temperature in Season 2. Similarly, statistically higher $(p<0.05)$ midday temperatures were recorded in Season 2 than Season 1 for the NHS environment. The morning weekly temperatures recorded in the NHS environment during Season 1 ranged from 15 to $27.54{ }^{\circ} \mathrm{C}$, while in the HS environment, the range was 16.38 to $30.96{ }^{\circ} \mathrm{C}$ (Figure 1 ). The afternoon weekly temperature recorded in the NHS environment ranged from 22.92 to $33.92{ }^{\circ} \mathrm{C}$ but varied between 26.1 and $40.88^{\circ} \mathrm{C}$ under the HS environment. The morning temperatures recorded from the Season 2 experiment in the NHS environment ranged from 16.2 to $28.12{ }^{\circ} \mathrm{C}$ while the readings ranged from 19.83 to $32.9^{\circ} \mathrm{C}$ under the HS environment. The range of afternoon temperatures observed in the NHS environment was from 25.9 to $32.5^{\circ} \mathrm{C}$, while the HS environment ranged from 32.69 to $44^{\circ} \mathrm{C}$. 

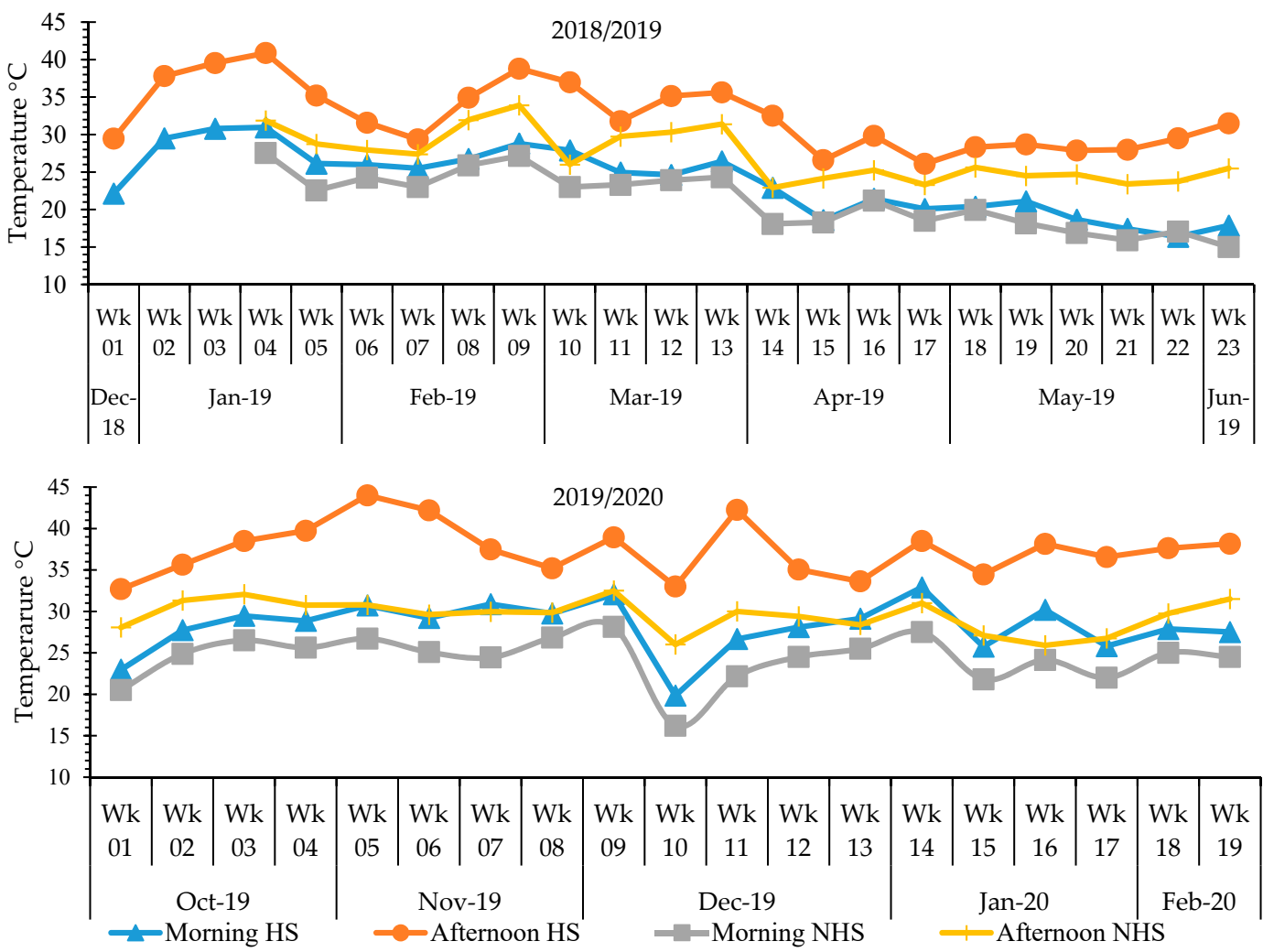

Figure 1. Weekly temperature records for HS and NHS environments during the 2018/2019 and 2019/2020 summer planting seasons.

\subsection{Main Effects of Planting Season on the Maize Growth Attributes and Dry Biomass Yield}

There were significant $(p \leq 0.05)$ seasonal effects on the studied maize attributes (Figure 2A-E). The measured growth attributes at 10 WAP namely leaf chlorophyll content $(17.6 \mathrm{CCI})$, leaf area $\left(353.4 \mathrm{~cm}^{2}\right)$, stem diameter $(21 \mathrm{~mm})$, and plant height at 20 WAP $(143.9 \mathrm{~cm})$ were significantly higher in Season 1 than in Season 2. Similarly, dry biomass yield (169.6 g plant $^{-1}$ ) and harvest index (31.1\%) were higher in Season 1 than Season 2 (Table 3). However, the number of leaves at 7 and $10 \mathrm{WAP}$, number of days until tassel (87 days) and silk (98 days) production, as well as tassel silk interval, were higher in Season 2 compared to Season 1.

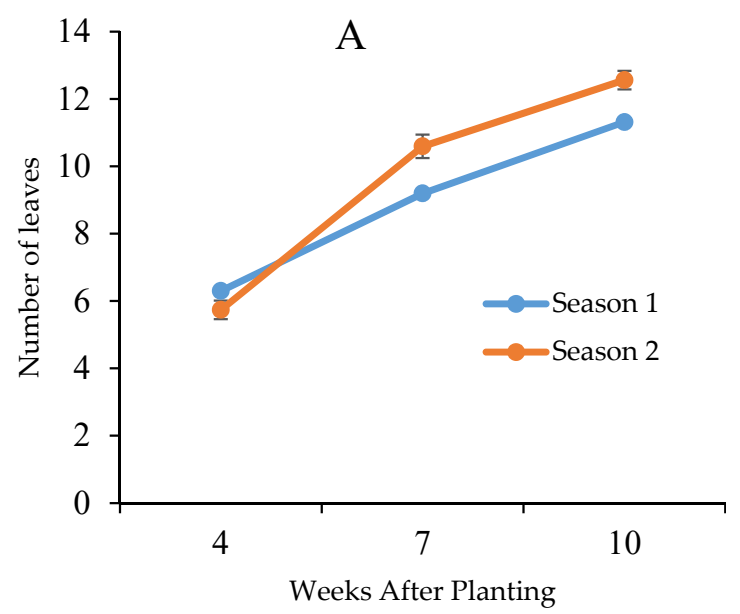

Figure 2. Cont. 

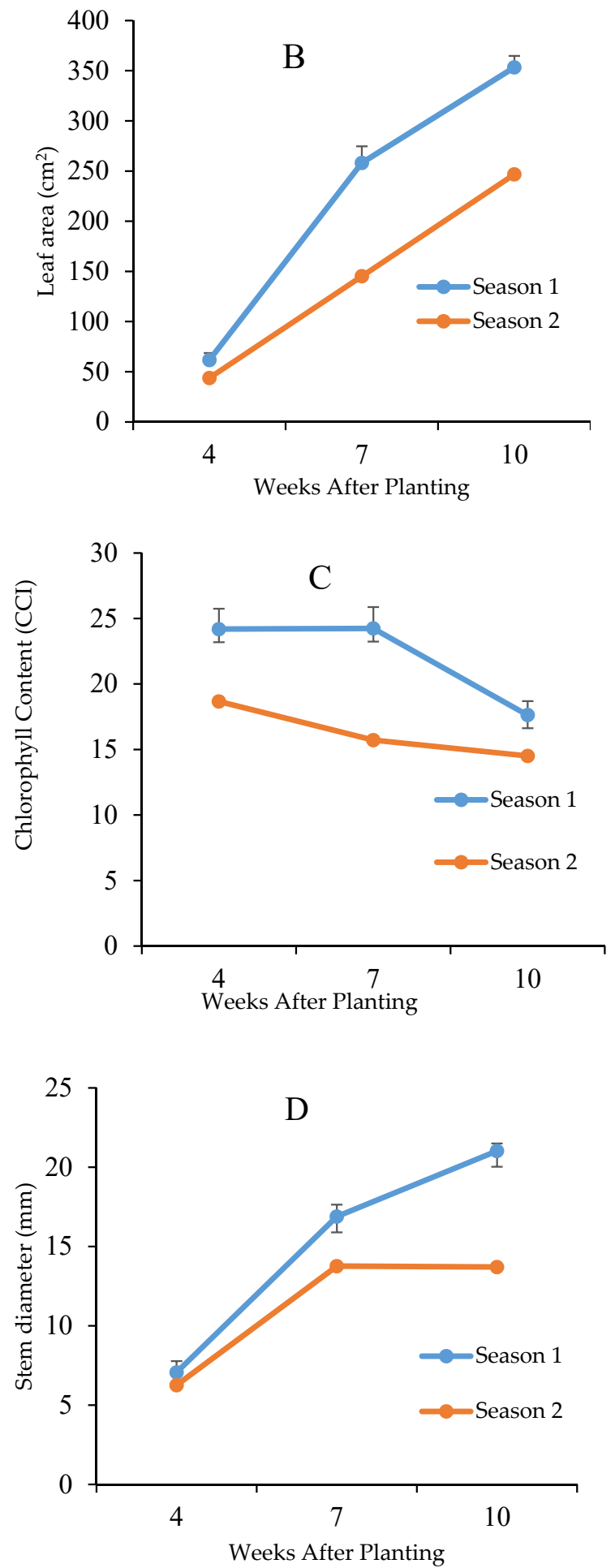

Figure 2. Cont. 


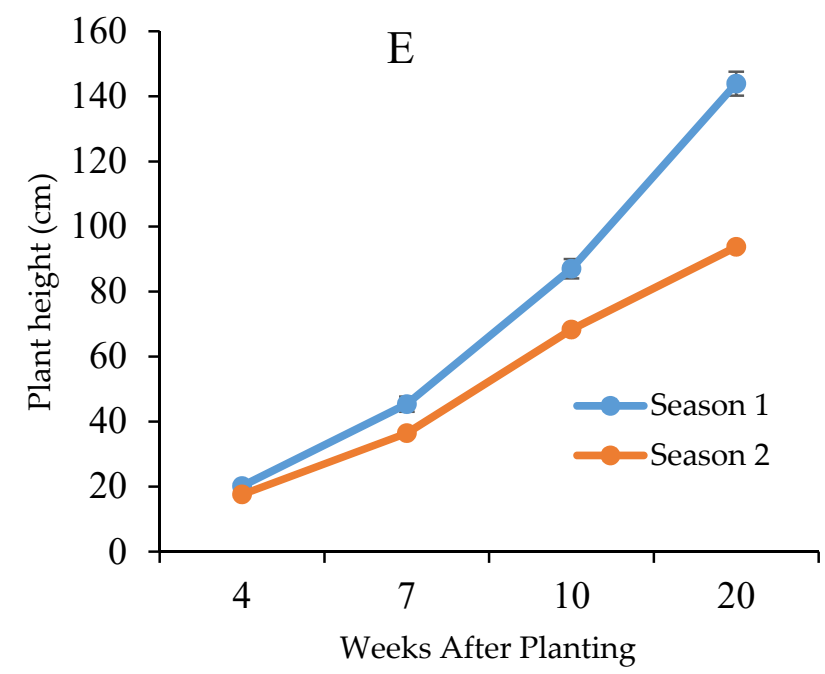

Figure 2. Main effects of planting seasons on the number of leaves (A), leaf area (B), leaf chlorophyll content (C), stem diameter (D), and plant height (E).

Table 3. Main effects of planting seasons on the phenological and biological yield indices of maize.

\begin{tabular}{|c|c|c|c|c|c|}
\hline Season & DT & DS & TSI & DBY & HI \\
\hline 1 & $67.2^{b}$ & $74.3^{b}$ & $7.1^{b}$ & $169.6^{\mathrm{a}}$ & $31.1^{\mathrm{a}}$ \\
\hline 2 & $86.8^{a}$ & $98.3^{a}$ & $11.4^{\mathrm{a}}$ & $69.3^{b}$ & $13.9^{b}$ \\
\hline F-LSD ${ }_{(0.05)}$ & 1.3 & 1.2 & 0.7 & 4.3 & 2.2 \\
\hline
\end{tabular}

Means with the same letter within the same column are not significantly different at $p \leq 0.05$, DT = number of days until tasselling, DS = number of days until silking, TSI = tassel silk interval, DBY $=$ dry biomass yield $\left(\mathrm{g} \mathrm{plant}^{-1}\right)$, and $\mathrm{HI}=$ harvest index $(\%)$.

Comparison of Season 1 and Season 2 morning relative humidity revealed a significantly $(p<0.001)$ higher relative humidity in Season 1 (Table 4$)$. There was no significant difference in the afternoon and night relative humidity for both seasons. The average amount of rain per rainfall day was $9.4 \mathrm{~mm}$ in Season 2 and $7.6 \mathrm{~mm}$ in Season 1. There were 55 and 40 rainfall days in Seasons 1 and 2, respectively. Season 2 was significantly $(p<0.001)$ higher than Season 1 in maximum and minimum temperatures.

Table 4. Comparison of the weather data for the two planting seasons.

\begin{tabular}{|c|c|c|c|c|c|c|c|}
\hline Treatment & Weather Variable & Size & Mean & $\begin{array}{l}\text { Standard } \\
\text { Deviation }\end{array}$ & $\begin{array}{c}\text { Test } \\
\text { Statistic }\end{array}$ & $\begin{array}{l}\text { Degree of } \\
\text { Freedom }\end{array}$ & Probability \\
\hline Season 1 & \multirow[t]{2}{*}{ Morning humidity } & 196 & 58.95 & 16.36 & \multirow[t]{2}{*}{3.45} & \multirow[t]{2}{*}{274.02} & \multirow[t]{2}{*}{$<0.001$} \\
\hline Season 2 & & 151 & 51.75 & 21.28 & & & \\
\hline Season 1 & \multirow[t]{2}{*}{ Afternoon humidity } & 197 & 31.51 & 15.58 & \multirow[t]{2}{*}{0.6} & \multirow[t]{2}{*}{282.9} & \multirow[t]{2}{*}{0.55} \\
\hline Season 2 & & 150 & 32.66 & 19.11 & & & \\
\hline Season 1 & \multirow[t]{2}{*}{ Night humidity } & 196 & 48.74 & 19.86 & \multirow[t]{2}{*}{0.92} & \multirow[t]{2}{*}{345} & \multirow[t]{2}{*}{0.359} \\
\hline Season 2 & & 151 & 46.63 & 22.9 & & & \\
\hline Season 1 & \multirow[t]{2}{*}{ Rainfall volume } & $55 *$ & 7.644 & 12.38 & \multirow[t]{2}{*}{0.65} & \multirow[t]{2}{*}{93} & \multirow[t]{2}{*}{0.517} \\
\hline Season 2 & & $40 *$ & 9.355 & 13.04 & & & \\
\hline Season 1 & \multirow{2}{*}{$\begin{array}{l}\text { Maximum } \\
\text { temperature }\end{array}$} & 194 & 29.78 & 5.109 & \multirow[t]{2}{*}{4.26} & \multirow[t]{2}{*}{340.69} & \multirow[t]{2}{*}{$<0.001$} \\
\hline Season 2 & & 150 & 31.81 & 3.706 & & & \\
\hline Season 1 & \multirow[t]{2}{*}{$\begin{array}{l}\text { Minimum } \\
\text { temperature }\end{array}$} & 194 & 13.89 & 5.62 & \multirow[t]{2}{*}{7.52} & \multirow[t]{2}{*}{274.51} & \multirow[t]{2}{*}{$<0.001$} \\
\hline Season 2 & & 150 & 17.27 & 2.392 & & & \\
\hline
\end{tabular}




\subsection{Main Effects of Heat Stress on the Maize Growth Attributes and Dry Biomass Yield}

Growth and yield attributes of maize were significantly $(p \leq 0.05)$ influenced by heat stress in this study. Heat stress exerted a depressive effect on the maize plant growth attributes, while the phenological attributes DT, DS, and TSI were not reduced (Figure 3A-E). At $10 \mathrm{WAP}$, heat stress reduced the leaf chlorophyll content and the leaf area by $35 \%$ and $36 \%$, respectively. A similar percentage reduction in the average number of leaves plant ${ }^{-1}$ and stem diameter was recorded under the HS environment relative to the NHS environment. The HS environment caused a 55\% reduction in maize plant height during the active growth stage at $10 \mathrm{WAP}$ but resulted in a $41 \%$ plant height reduction at crop harvest. Similarly, dry biomass yield dropped from $158.9 \mathrm{~g} \mathrm{plant}^{-1}$ in the NHS environment to $54.4 \mathrm{~g} \mathrm{plant}^{-1}$ in the HS environment accounting for $59 \%$ dry matter loss, while up to $78 \%$ yield reduction in the harvest index was recorded due to the HS environment (Table 5).
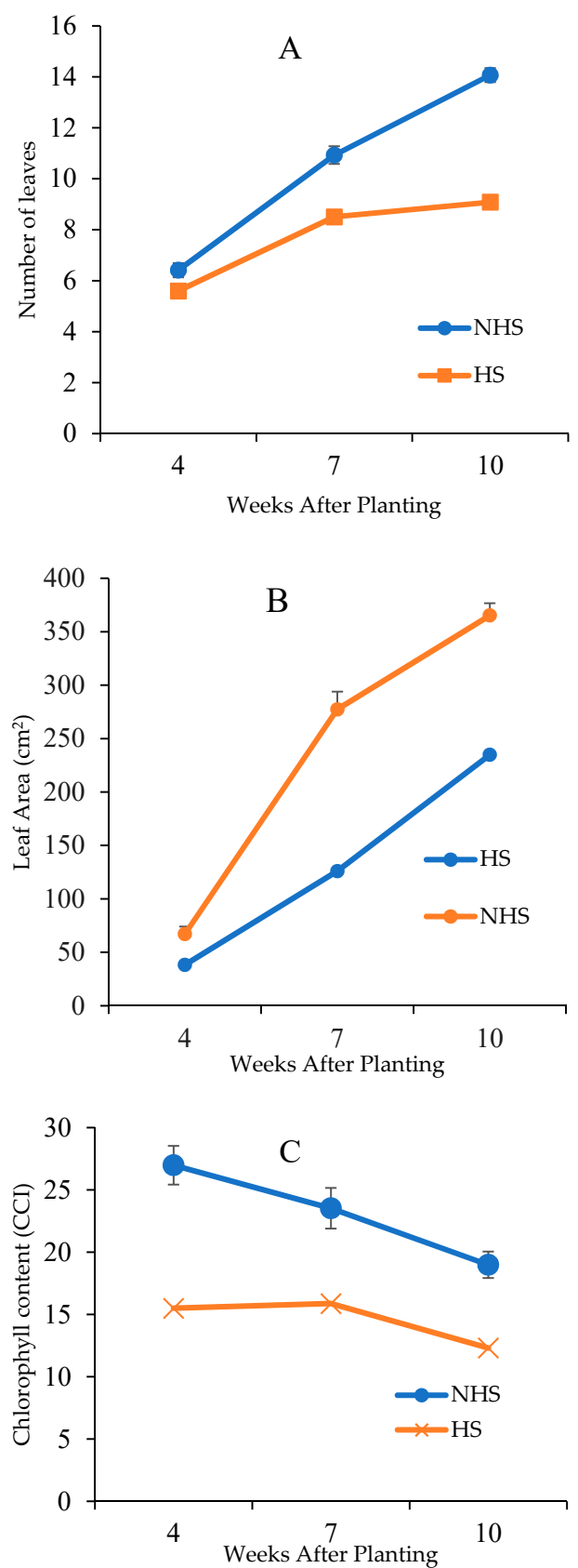

Figure 3. Cont. 

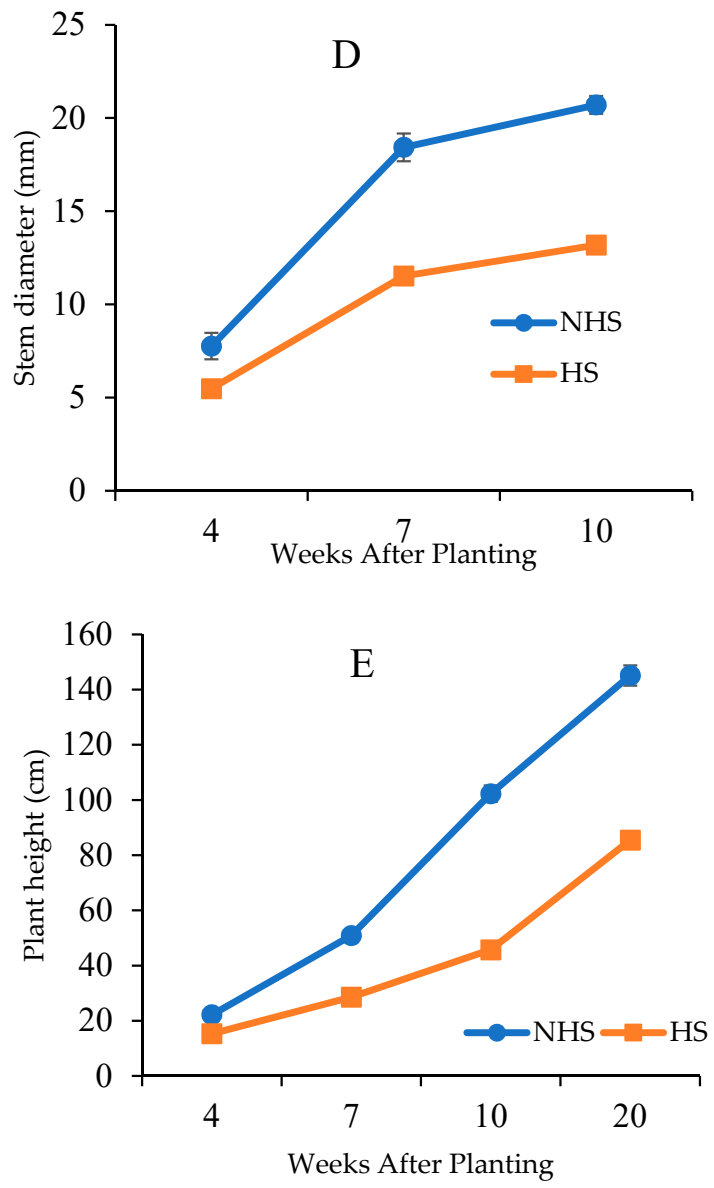

Figure 3. Main effects of heat stress on the maize number of leaves (A), leaf area (B), leaf chlorophyll content (C), stem diameter (D), and plant height (E).

Table 5. Main effects of growth environment on maize phenological and biological yield indices.

\begin{tabular}{|c|c|c|c|c|c|}
\hline Heat stress & DT & DS & TSI & DBY & HI \\
\hline Non-Heat Stress (NHS) & $74.3^{b}$ & $82.4^{b}$ & $8.2^{b}$ & $158.9^{\mathrm{a}}$ & $34.2^{\mathrm{a}}$ \\
\hline Heat Stress (HS) & $77.4^{\mathrm{a}}$ & $87.9^{a}$ & $10.5^{\mathrm{a}}$ & $65.4^{\mathrm{b}}$ & $7.6^{b}$ \\
\hline F-LSD $_{(0.05)}$ & 1.3 & 1.2 & 0.7 & 4.3 & 2.2 \\
\hline
\end{tabular}

Means with the same letter within the same column are not significantly different at $p \leq 0.05$, DT = number of days until tasselling, DS = number of days until silking, TSI = tassel silk interval, DBY = dry biomass yield $\left(\mathrm{g} \mathrm{plant}^{-1}\right)$, and $\mathrm{HI}=$ harvest index $(\%)$.

\subsection{Main Effects of Variety on the Growth Attributes and Dry Biomass Yield of Maize}

Maize variety caused significant $(p \leq 0.05)$ variations in the mean number of leaves, leaf area, leaf chlorophyll content, stem diameter, plant height, and phenological and biological yield indices. At $10 \mathrm{WAP}, \mathrm{ZM} 1523$ produced the highest number of leaves, leaf chlorophyll content, and plant height (Figure 4A,C,E). However, the highest plant height at 20 WAP was obtained from WE3128. The WE5323 variety gave the widest leaf area and stem diameter at 10 WAP (Figure 4B,D). 

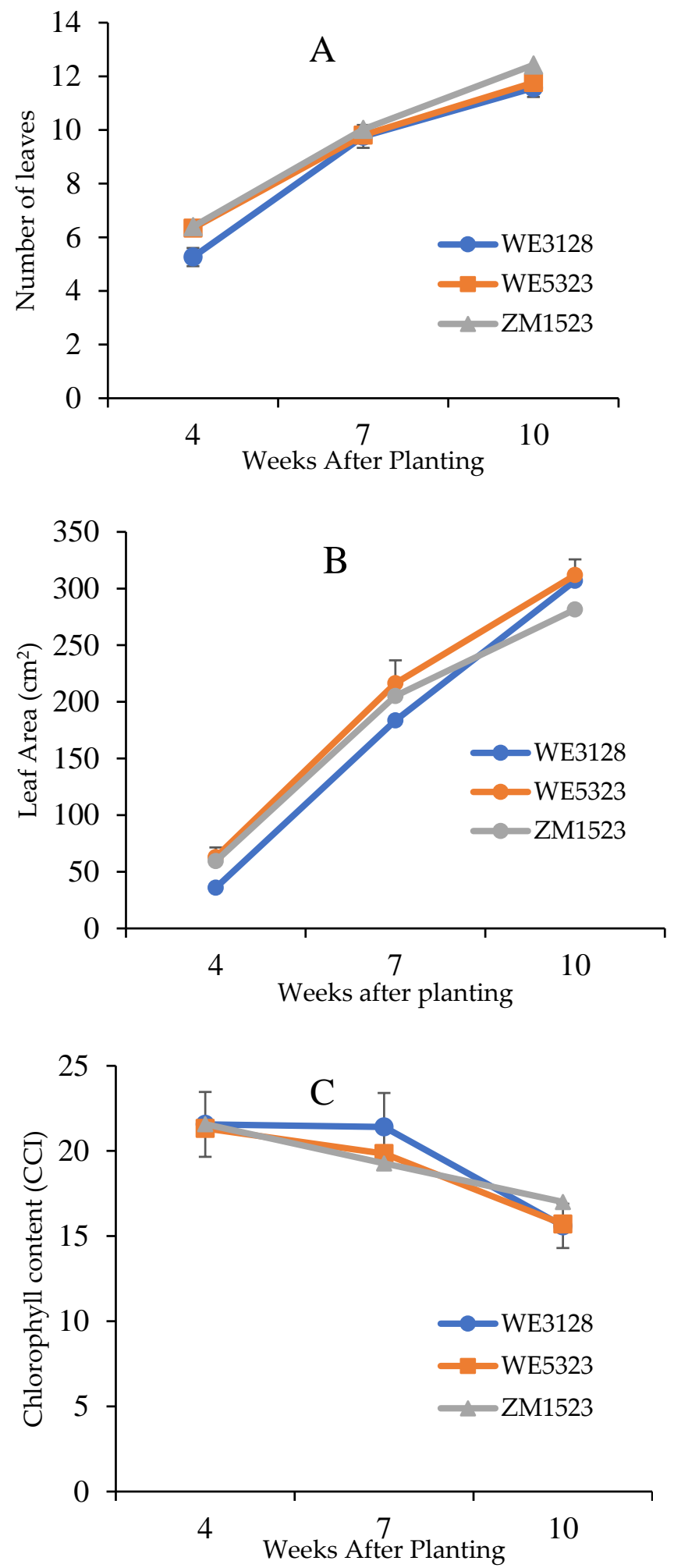

Figure 4. Cont. 

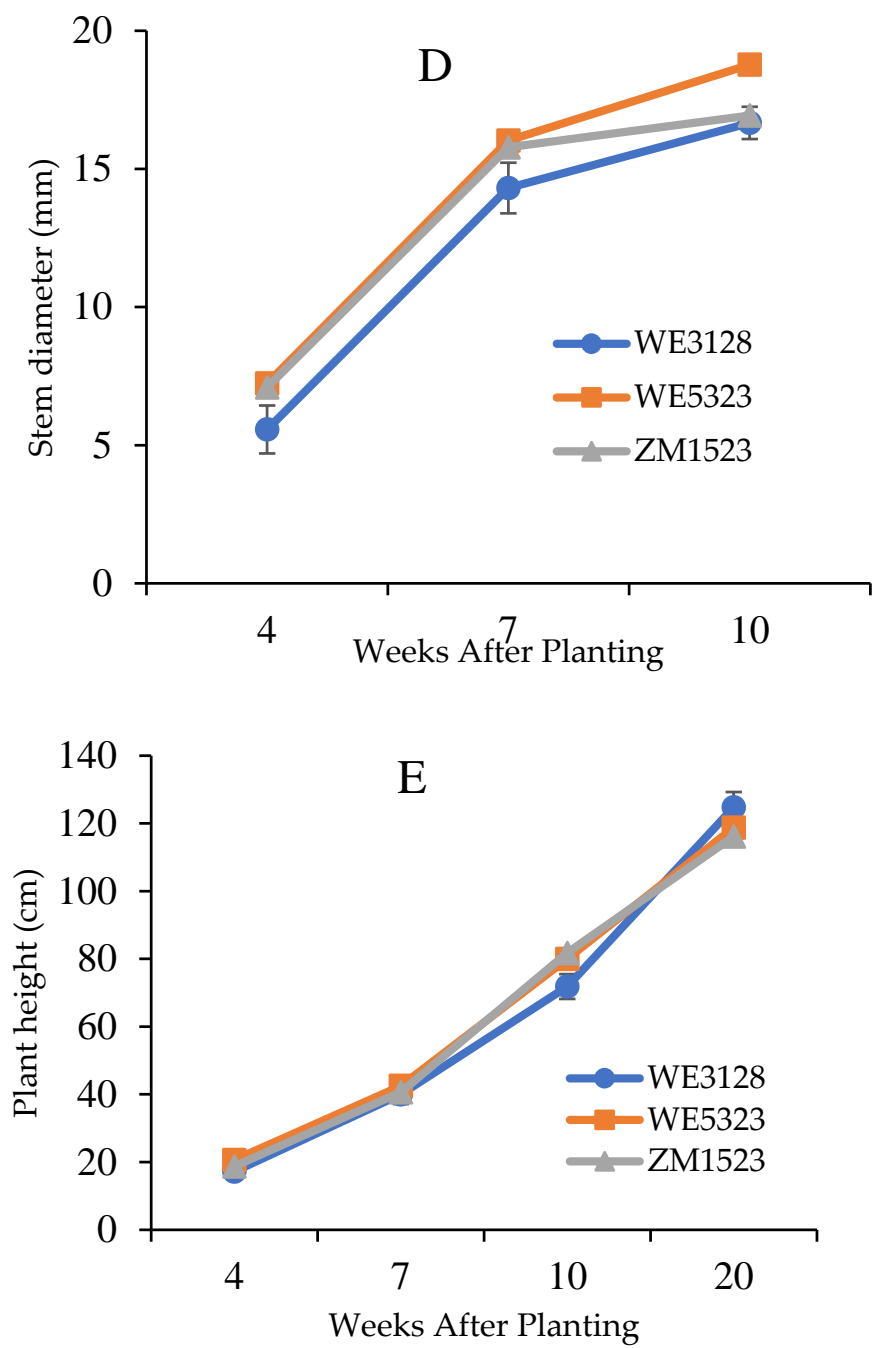

Figure 4. Main effects of variety on the maize number of leaves (A), leaf area (B), leaf chlorophyll content $(\mathbf{C})$, stem diameter (D), and plant height (E).

The WE3128 variety took the significantly highest number of days to produce tassel and silk with the shortest tassel silk interval (Table 6). On the contrary, ZM1523 took the significantly least number of days until tassel and silk production with the highest tassel silk interval. It produced the least dry biomass yield and the highest harvest index, while WE3128 gave the highest dry biomass yield and the lowest harvest index. Dry biomass yield ranged from $114.9 \mathrm{~g} \mathrm{plant}^{-1}$ in ZM1523 to $125.1 \mathrm{~g} \mathrm{plant}^{-1}$ in WE3128, while harvest index ranged from $19.2 \%$ in WE3128 to $25 \%$ in ZM1523.

Table 6. The main effect of variety on phenological and biological yield indices of maize.

\begin{tabular}{cccccc}
\hline Maize Variety & DT & DS & TSI & DBY & HI \\
\hline WE3128 & $79.9^{\mathrm{a}}$ & $86.7^{\mathrm{a}}$ & $6.8^{\mathrm{b}}$ & $125.1^{\mathrm{a}}$ & $19.2^{\mathrm{b}}$ \\
WE5323 $_{\text {ZM1523 }}$ & $74.7^{\mathrm{b}}$ & $84.3^{\mathrm{b}}$ & $9.6^{\mathrm{a}}$ & $121.8^{\mathrm{a}}$ & $21.3^{\mathrm{b}}$ \\
F-LSD $_{(0.05)}$ & $71.7^{\mathrm{c}}$ & $81.6^{\mathrm{c}}$ & $9.9^{\mathrm{a}}$ & $114.9^{\mathrm{b}}$ & $25.0^{\mathrm{a}}$ \\
\hline
\end{tabular}

Means with the same letter within the same column are not significantly different at $p \leq 0.05$, DT $=$ number of days until tasselling, DS = number of days until silking, TSI = tassel silk interval, DBY = dry biomass yield $\left(\mathrm{g}\right.$ plant $\left.{ }^{-1}\right)$, and $\mathrm{HI}=$ harvest index $(\%)$. 


\subsection{Main Effects of Soil Amendment on the Maize Growth Attributes and Dry Biomass Yield}

Significant $(p \leq 0.05)$ differences due to the soil amendments were observed in the number of leaves, leaf area, leaf chlorophyll content, stem diameter, plant height, and number of days until tassel and silk production as well as dry biomass yield (Figure 5A-E). MF amendment favoured an increase in the number of leaves, stem diameter, and plant height. The number of leaves and stem diameter observed in the MF did not differ from the observations in the MPM amendment at 10 WAP. Similarly, in this period, there was no statistical difference between MPM and PM amendments in the leaf area. However, PM was significantly $(p \leq 0.05)$ higher than the MPM and MF in leaf chlorophyll content. PM amendment accounted for the highest number of days until tassel and silk production as well as dry biomass yield and harvest index (Table 7). The dry biomass yield ranged from $87.3 \mathrm{~g} \mathrm{plant}^{-1}$ in the MF to $139.8 \mathrm{~g} \mathrm{plant}^{-1}$ in the PM. The harvest index ranged from $21.1 \%$ in the MF to $22.6 \%$ in the PM. There was no significant effect of soil amendment on the harvest index.
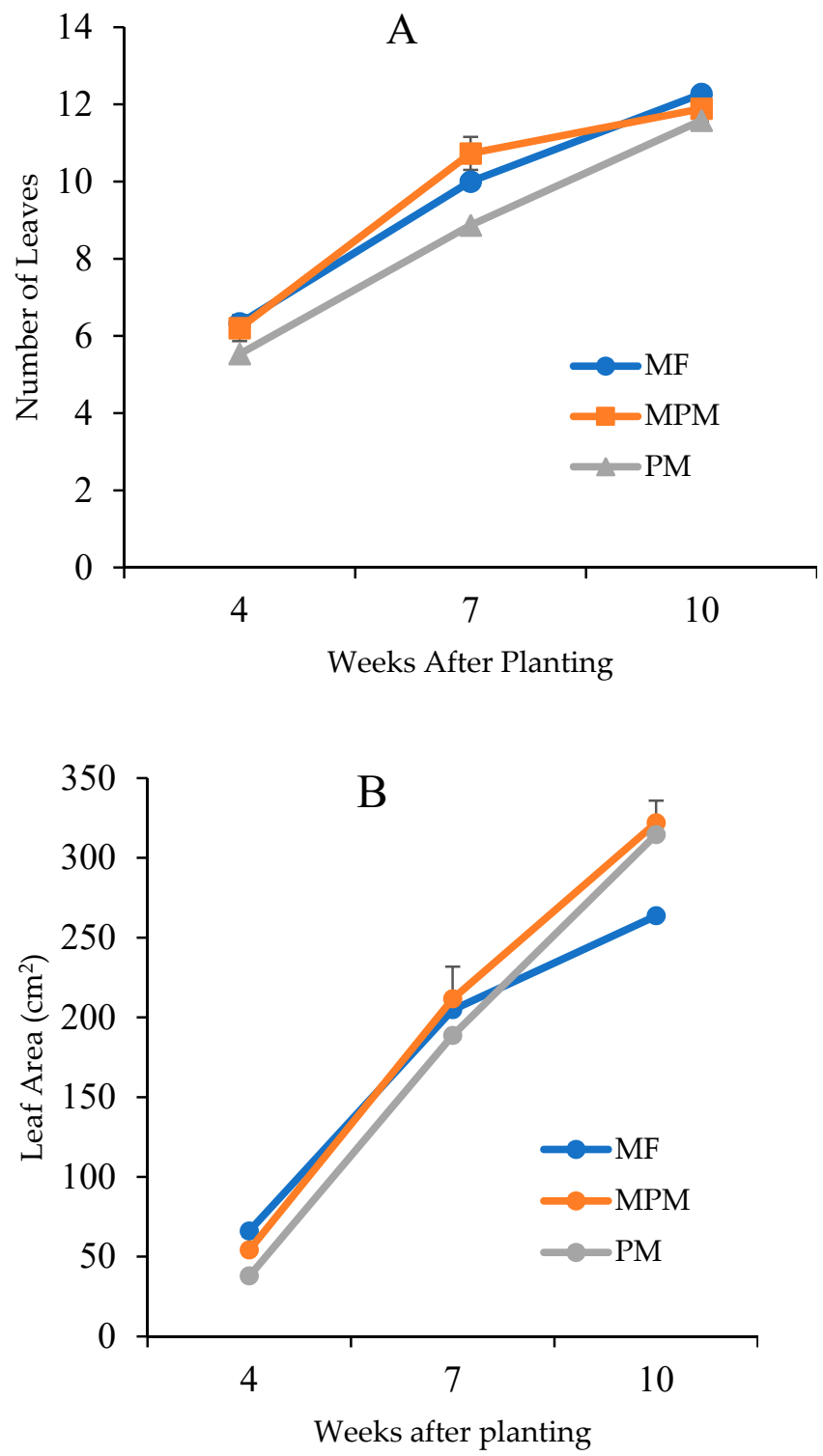

Figure 5. Cont. 

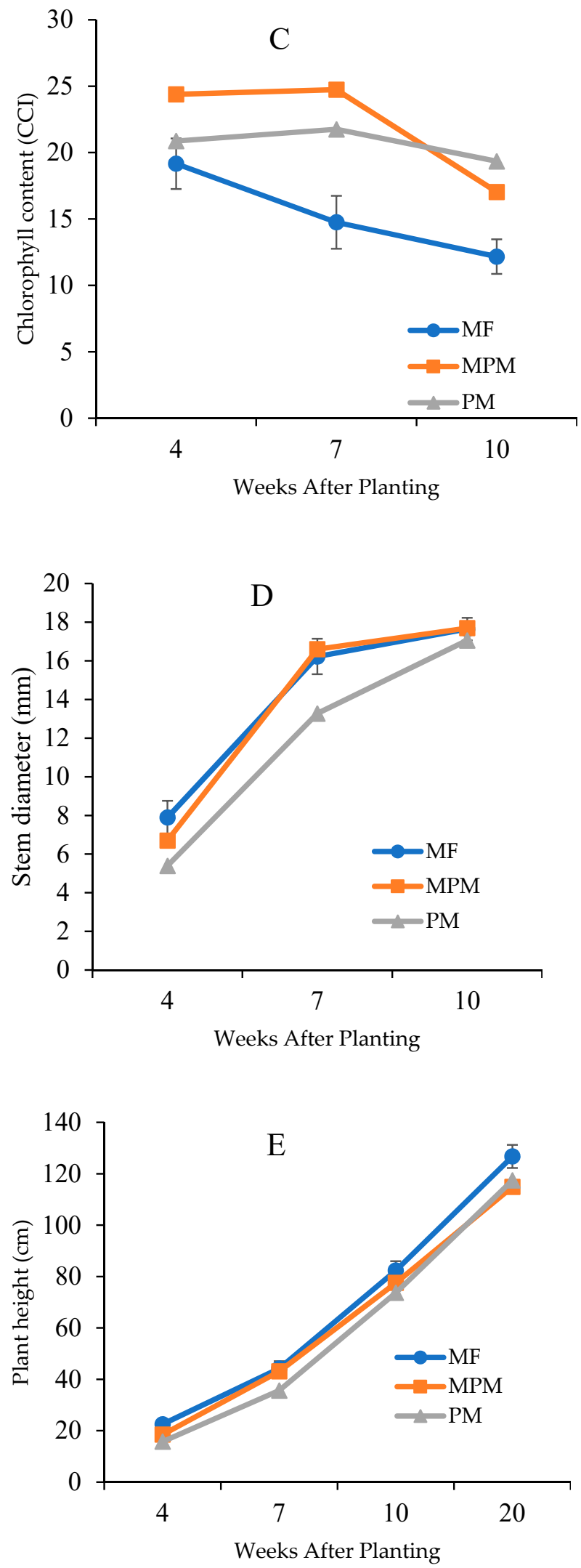

Figure 5. Main effects of soil amendment on the maize number of leaves (A), leaf area (B), chlorophyll content (C), stem diameter (D), and plant height (E). 
Table 7. The main effect of soil amendment on the phenological and biological yield indices of maize.

\begin{tabular}{cccccc}
\hline Soil Amendment & DT & DS & TSI & DBY & HI \\
\hline Poultry manure (PM) & $78.0^{\mathrm{a}}$ & $86.5^{\mathrm{a}}$ & $8.5^{\mathrm{b}}$ & $139.8^{\mathrm{a}}$ & $22.6^{\mathrm{a}}$ \\
Mineral fertilizers / Poultry manure (MPM) & $74.1^{\mathrm{b}}$ & $82.3^{\mathrm{b}}$ & $8.2^{\mathrm{b}}$ & $135.9^{\mathrm{a}}$ & $21.9^{\mathrm{a}}$ \\
Mineral fertilizers (MF) & $73.7^{\mathrm{b}}$ & $83.5^{\mathrm{b}}$ & $9.8^{\mathrm{a}}$ & $87.3^{\mathrm{b}}$ & $21.2^{\mathrm{a}}$ \\
F-LSD $_{(0.05)}$ & 1.5 & 1.4 & 0.9 & 5.3 & n.s \\
\hline
\end{tabular}

Means with the same letter within the same column are not significantly different at $p \leq 0.05$, n.s. $=$ non-significant, DT $=$ number of days until tasselling, DS = number of days until silking, TSI = tassel silk interval, DBY $=$ dry biomass yield $\left(\mathrm{g}\right.$ plant $\left.{ }^{-1}\right)$, and $\mathrm{HI}=\mathrm{harves}$ index $(\%)$

\subsection{Main Effects of Soil Type on the Growth Attributes and Dry Biomass Yield of Maize}

Soil type had a significant $(p \leq 0.05)$ influence on the studied maize attributes, except for the number of days until silk production and harvest index (Figure 6A-E). Maize plants grown on SCL soil produced a higher number of leaves, leaf chlorophyll content, stem diameter, and plant height than those grown in the LS soil. The latter was higher in the leaf area. On the phenological attributes, a higher number of days until tassel and silk production was recorded for SCL, while LS was higher in tassel silk interval (Table 8). SCL soil also produced a higher dry biomass yield and harvest index than LS soil.
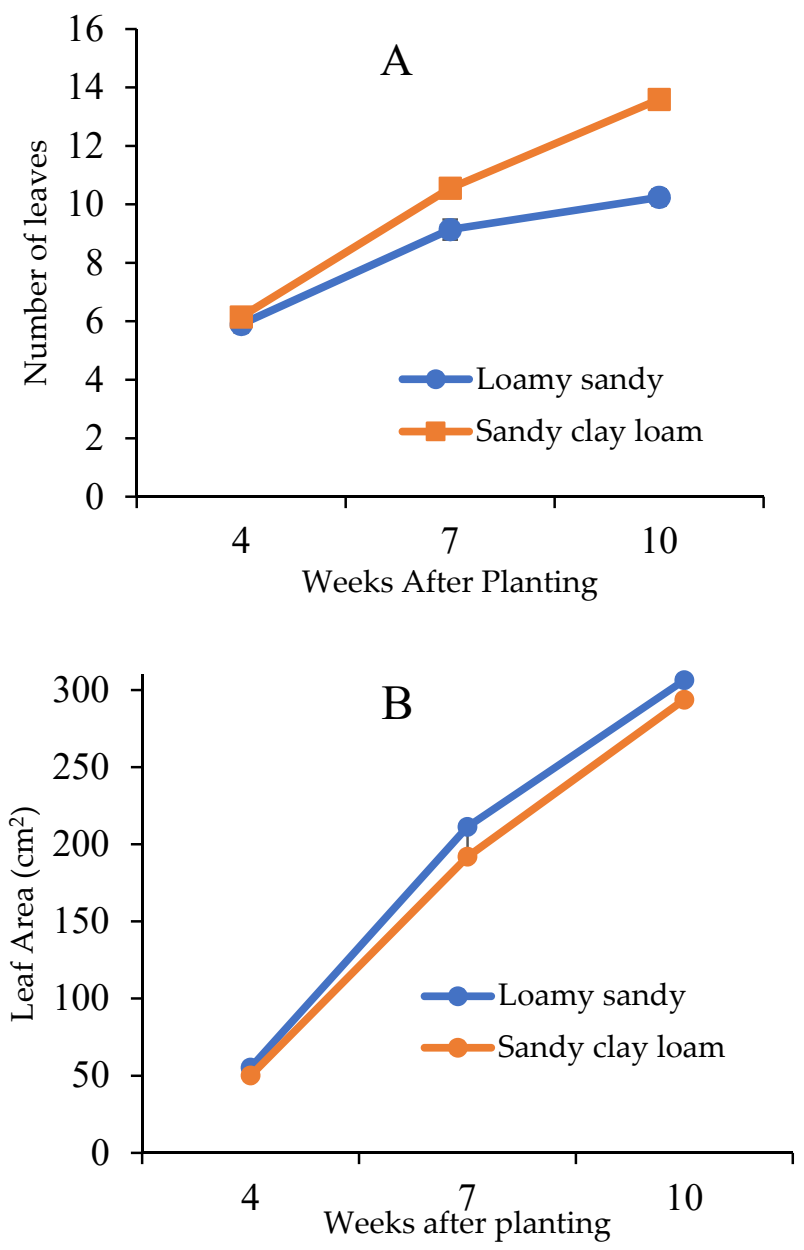

Figure 6. Cont. 

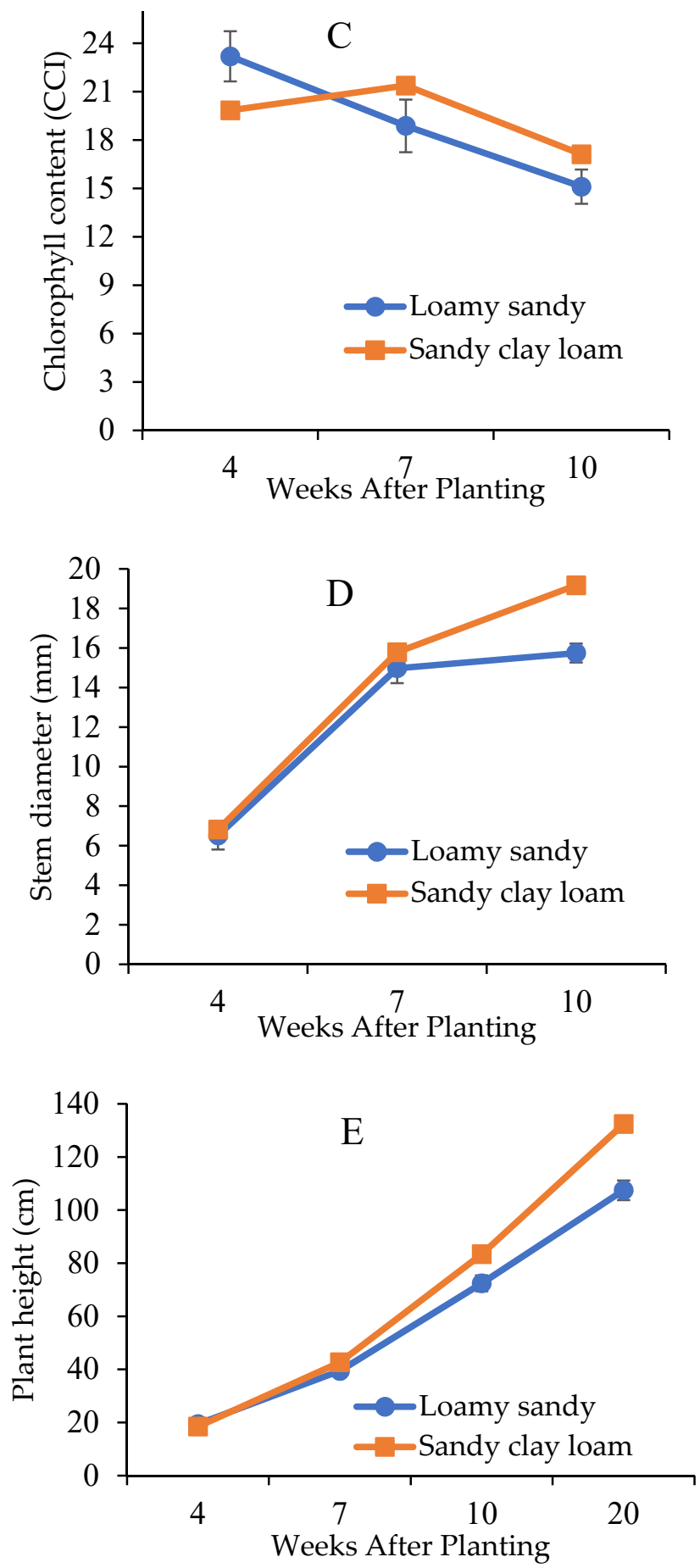

Figure 6. Main effects of soil type on the maize number of leaves (A), leaf area (B), leaf chlorophyll content (C), stem diameter (D), and plant height (E).

Table 8. Main effects of soil type on the phenological and biological yield indices of maize.

\begin{tabular}{|c|c|c|c|c|c|}
\hline Soil Type & DT & DS & TSI & DBY & HI \\
\hline Loamy sand & $74.3^{b}$ & $83.6^{\mathrm{a}}$ & $9.3^{\mathrm{a}}$ & $107.6^{b}$ & $21.5^{\mathrm{a}}$ \\
\hline Sandy clay loam & $75.9^{\mathrm{a}}$ & $84.4^{\mathrm{a}}$ & $8.5^{b}$ & $134.3^{\mathrm{a}}$ & $22.3^{\mathrm{a}}$ \\
\hline F-LSD $(0.05)$ & 1.3 & n.s & 0.7 & 4.3 & n.s \\
\hline
\end{tabular}

Means with the same letter within the same column are not significantly different at $p \leq 0.05$, n.s. = non-significant, $\mathrm{DT}=$ number of days until tasselling, DS = number of days until silking, TSI = tassel silk interval, DBY = dry biomass yield $\left(\mathrm{g}\right.$ plant $\left.{ }^{-1}\right)$, and $\mathrm{HI}=$ harvest index $(\%)$. 
3.7. The Interaction of Heat Stress, Maize Variety, Soil Amendment, and Soil Type on the Maize Growth and Yield Attributes

Significant interactions were observed in all the measured attributes for the first-order treatment interactions (Table 9). Excluding plant height and harvest index for environment $x$ maize variety $x$ soil type interaction, the remaining second-and third-order interactions caused significant variations on the studied attributes.

Table 9. First-, second-, and third-order interactions of maize variety, heat stress, soil amendment, and soil type on the maize growth and yield attributes.

\begin{tabular}{cccccccccccc}
\hline $\begin{array}{c}\text { Treatment } \\
\text { Interactions }\end{array}$ & NOL LA & CC & SD & PH & FPH & DT & DS & TSI & DBY & HI \\
\hline HS.MV & $* *$ & $* *$ & $*$ & $* *$ & $* *$ & $* *$ & $* *$ & $* *$ & $* *$ & $* *$ & $*$ \\
HS.SA & $* *$ & $* *$ & $* *$ & $* *$ & $*$ & $*$ & $* *$ & $*$ & $* *$ & $* *$ & $*$ \\
MV.SA & $* *$ & $* *$ & $*$ & $*$ & $*$ & $* *$ & $* *$ & $* *$ & $* *$ & $*$ & $*$ \\
HS.ST & $* *$ & $*$ & $* *$ & $* *$ & $* *$ & $* *$ & $* *$ & $* *$ & $* *$ & $* *$ & $*$ \\
MV.ST & $* *$ & $*$ & $*$ & $* *$ & $*$ & $*$ & $* *$ & $* *$ & $*$ & $* *$ & $*$ \\
SA.ST & $* *$ & $* *$ & $*$ & $* *$ & $* *$ & $* *$ & $* *$ & $* *$ & $* *$ & $* *$ & $*$ \\
HS.MV.SA & $* *$ & $* *$ & $* *$ & $* *$ & $* *$ & $* *$ & $* *$ & $* *$ & $* *$ & $* *$ & $*$ \\
HS.MV.ST & $* *$ & $*$ & $*$ & $* *$ & n.s & $*$ & $* *$ & $* *$ & $* *$ & $*$ & n.s \\
HS.SA.ST & $* *$ & $* *$ & $* *$ & $* *$ & $* *$ & $* *$ & $* *$ & $* *$ & $* *$ & $* *$ & $*$ \\
MV.SA.ST & $* *$ & $* *$ & $*$ & $*$ & $*$ & $* *$ & $* *$ & $* *$ & $* *$ & $* *$ & $*$ \\
HS.MV.SA.ST & $* *$ & $* *$ & $*$ & $* *$ & $*$ & $* *$ & $* *$ & $* *$ & $* *$ & $*$ & $*$
\end{tabular}

n.s $=$ not significant, ${ }^{*}=$ significant at $5 \%$ probability level, ${ }^{* *}=$ significant at $1 \%$ probability level, HS $=$ heat stress, $\mathrm{MV}=$ maize variety, $\mathrm{SA}=$ soil amendment, $\mathrm{ST}=$ soil type, $\mathrm{NOL}=$ number of leaves at $10 \mathrm{WAP}, \mathrm{LA}=$ leaf area $\left(\mathrm{cm}^{2}\right)$ at $10 \mathrm{WAP}, \mathrm{CC}=$ leaf chlorophyll content $(\mathrm{CCI})$ at $10 \mathrm{WAP}, \mathrm{PH}=$ plant height $(\mathrm{cm})$ at $10 \mathrm{WAP}, \mathrm{FPH}=$ plant height $(\mathrm{cm})$ at 20 WAP DT $=$ number of days until tasselling, DS = number of days until silking, TSI $=$ tassel silk interval, DBY $=$ dry biomass yield $\left(\mathrm{g} \mathrm{plant}^{-1}\right)$, and $\mathrm{HI}=$ harvest index $(\%)$.

There were significant interactions of heat stress, maize variety, and soil amendment on the number of leaves, leaf area, leaf chlorophyll content, stem diameter, plant height, number of days until tassel and silk production, and dry biomass yield and harvest index of the maize. The number of leaves ranged from 4.2 to $7.3,7.3$ to 11.9 , and 9.9 to 15.4 at 4,7 , and 10 WAP, respectively (Table 10). The NHS-ZM1-MPM interaction gave the highest number of leaves at 4, 7, and 10 WAP. Under the heat-stress environment, the HS-ZM1-MF interaction gave the highest number of leaves at $10 \mathrm{WAP}$.

The largest leaf area at 10 WAP was produced by NHS-WE3-MPM. Under the heatstress environment, the HS-WE5-MPM interaction gave the largest leaf area at $10 \mathrm{WAP}$. The ranges for the leaf area at 4, 7, and 10 WAP were 21-92.2, 100.5-323.2, and 218.2-421.2 $\mathrm{cm}^{2}$, respectively. The leaf chlorophyll content ranged from 13 to $34.6 \mathrm{CCI}$ at $4 \mathrm{WAP}, 13$ to 31.8 CCI at 7 WAP, and 11 to 25 CCI at 10 WAP. The NHS-WE5-PM interaction gave the highest leaf chlorophyll content at 10 WAP. Among the heat-stressed plants at 10 WAP, the HS-WE5-MPM interaction produced the highest leaf chlorophyll content.

The stem diameter was significantly influenced by the applied treatment interactions. At 10 WAP, the NHS-WE5-MPM interaction produced the thickest stem diameter, which was similar to the NHS-WE5-PM, but significantly higher than the other treatment interactions (Table 11). The stem diameter ranged from 3.8 to $9.1 \mathrm{~mm}$ at $4 \mathrm{WAP}, 10.0$ to $21.0 \mathrm{~mm}$ at $7 \mathrm{WAP}$, and 14.4 to $23.8 \mathrm{~mm}$ at $10 \mathrm{WAP}$. The ranges for the plant height at $4,7,10$, and 20 WAP were 11.9-27.2, 25.0-57.3, 44.0-14.2, and 97.5-162.4 cm, respectively. The tallest plants at 10 and 20 WAP were produced by NHS-ZM1-MF and NHS-WE3-MF interactions, respectively. In the heat-stress environment, the HS-WE5-MPM interaction gave the highest plant height at 10 and 20 WAP. 
Table 10. Interaction of heat stress, maize variety, and soil amendment on the maize number of leaves, leaf area, and chlorophyll content.

\begin{tabular}{|c|c|c|c|c|c|c|c|c|c|c|}
\hline \multirow[t]{2}{*}{ SN } & \multirow[t]{2}{*}{ Treatment Interactions } & \multicolumn{3}{|c|}{ Number of Leaves } & \multicolumn{3}{|c|}{ Leaf Area $\left(\mathrm{cm}^{2}\right)$} & \multicolumn{3}{|c|}{ Chlorophyll Content (CCI) } \\
\hline & & 4 WAP & 7 WAP & $10 \mathrm{WAP}$ & 4 WAP & 7 WAP & 10 WAP & 4 WAP & 7 WAP & 10 WAP \\
\hline N1 & NHS-WE3-MF & 5.9 & 10.5 & 13.4 & 55.9 & 297.7 & 338.4 & 23.8 & 19.8 & 13.9 \\
\hline N2 & NHS-WE3-MPM & 5.5 & 11.8 & 15.0 & 43.4 & 257.0 & 421.2 & 30.6 & 31.8 & 20.4 \\
\hline N3 & NHS-WE3-PM & 5.4 & 10.9 & 14.6 & 21.0 & 232.2 & 417.0 & 27.7 & 28.3 & 21.8 \\
\hline N4 & NHS-WE5-MF & 6.4 & 9.8 & 13.1 & 92.2 & 274.5 & 302.2 & 19.5 & 13.1 & 11.0 \\
\hline N5 & NHS-WE5-MPM & 7.2 & 11.3 & 14.2 & 91.8 & 323.2 & 384.5 & 34.6 & 25.6 & 17.1 \\
\hline N6 & NHS-WE5-PM & 6.2 & 10.8 & 13.7 & 57.9 & 292.9 & 419.9 & 26.9 & 27.5 & 25.0 \\
\hline N7 & NHS-ZM1-MF & 6.7 & 10.1 & 12.9 & 76.2 & 250.3 & 268.4 & 20.8 & 14.6 & 14.5 \\
\hline N8 & NHS-ZM1-MPM & 7.3 & 11.9 & 15.4 & 90.9 & 318.6 & 351.2 & 30.2 & 24.7 & 22.2 \\
\hline N9 & NHS-ZM1-PM & 7.1 & 11.6 & 14.3 & 74.7 & 249.8 & 384.9 & 28.8 & 26.4 & 25.0 \\
\hline H1 & HS-WE3-MF & 6.3 & 9.5 & 10.8 & 50.1 & 148.0 & 218.2 & 19.8 & 13.0 & 11.8 \\
\hline $\mathrm{H} 2$ & HS-WE3-MPM & 5.2 & 9.0 & 10.0 & 22.8 & 109.5 & 270.6 & 13.0 & 17.9 & 13.5 \\
\hline H3 & HS-WE3-PM & 4.2 & 7.3 & 10.3 & 28.2 & 100.5 & 247.5 & 13.5 & 16.7 & 20.6 \\
\hline $\mathrm{H} 4$ & HS-WE5-MF & 6.7 & 10.3 & 12.2 & 63.8 & 126.5 & 234.3 & 14.8 & 14.5 & 12.0 \\
\hline H5 & HS-WE5-MPM & 5.8 & 9.6 & 9.9 & 43.3 & 145.6 & 298.7 & 16.3 & 24.3 & 21.0 \\
\hline H6 & HS-WE5-PM & 5.6 & 8.4 & 11.0 & 28.9 & 141.6 & 273.4 & 15.2 & 19.0 & 15.2 \\
\hline $\mathrm{H} 7$ & HS-ZM1-MF & 6.0 & 9.8 & 13.0 & 55.0 & 124.6 & 223.4 & 16.5 & 13.1 & 11.9 \\
\hline $\mathrm{H} 8$ & HS-ZM1-MPM & 6.1 & 9.6 & 11.3 & 34.5 & 151.6 & 242.2 & 19.5 & 20.5 & 17.7 \\
\hline \multirow[t]{2}{*}{$\mathrm{H} 9$} & HS-ZM1-PM & 5.2 & 7.9 & 11.1 & 24.7 & 183.0 & 275.4 & 13.6 & 21.6 & 17.4 \\
\hline & F-LSD $(0.05)$ & 0.8 & 1.1 & 0.8 & 21.1 & 49.7 & 34.0 & 4.7 & 4.9 & 3.2 \\
\hline
\end{tabular}

WAP = weeks after planting, NHS = non-heat-stress, HS = heat stress, WE3 = WE3128, WE5 = WE5323, ZM1 = ZM1523, MF = mineral fertilizers, $\mathrm{PM}=$ poultry manure, and MPM = complementary application of mineral fertilizer with poultry manure.

Table 11. Interaction of heat stress, maize variety, and soil amendment on the maize stem diameter and plant height.

\begin{tabular}{|c|c|c|c|c|c|c|c|c|}
\hline \multirow[t]{2}{*}{ SN } & \multirow{2}{*}{$\begin{array}{l}\text { Treatment } \\
\text { Interactions }\end{array}$} & \multicolumn{3}{|c|}{ Stem Diameter (mm) } & \multicolumn{4}{|c|}{ Plant Height (cm) } \\
\hline & & 4 WAP & 7 WAP & 10 WAP & 4 WAP & 7 WAP & 10 WAP & 20 WAP \\
\hline N1 & NHS-WE3-MF & 9.1 & 18.3 & 20.1 & 23.7 & 57.3 & 104.1 & 162.4 \\
\hline N2 & NHS-WE3-MPM & 6.1 & 17.7 & 21.9 & 19.8 & 45.7 & 94.2 & 156.3 \\
\hline N3 & NHS-WE3-PM & 4.5 & 15.3 & 20.4 & 15.3 & 45.2 & 92.1 & 153.1 \\
\hline N4 & NHS-WE5-MF & 8.9 & 19.6 & 18.9 & 27.2 & 52.6 & 109.4 & 148.0 \\
\hline N5 & NHS-WE5-MPM & 8.9 & 21.0 & 23.8 & 25.8 & 56.5 & 95.4 & 129.7 \\
\hline N6 & NHS-WE5-PM & 6.9 & 18.4 & 23.1 & 20.3 & 48.7 & 96.6 & 137.9 \\
\hline N7 & NHS-ZM1-MF & 8.4 & 18.2 & 17.3 & 24.4 & 51.3 & 114.2 & 144.6 \\
\hline N8 & NHS-ZM1-MPM & 9.0 & 19.7 & 20.3 & 21.6 & 53.8 & 112.8 & 133.1 \\
\hline N9 & NHS-ZM1-PM & 8.1 & 17.6 & 20.4 & 21.9 & 46.8 & 101.8 & 141.0 \\
\hline $\mathrm{H} 1$ & HS-WE3-MF & 6.2 & 13.0 & 15.2 & 18.9 & 35.0 & 44.0 & 106.5 \\
\hline $\mathrm{H} 2$ & HS-WE3-MPM & 4.1 & 10.9 & 14.6 & 14.0 & 27.0 & 57.6 & 109.9 \\
\hline $\mathrm{H} 3$ & HS-WE3-PM & 3.8 & 10.0 & 14.4 & 13.2 & 25.0 & 52.7 & 101.6 \\
\hline $\mathrm{H} 4$ & HS-WE5-MF & 7.6 & 14.1 & 19.2 & 21.7 & 36.4 & 61.8 & 108.1 \\
\hline H5 & HS-WE5-MPM & 5.9 & 12.4 & 16.8 & 14.4 & 31.3 & 68.2 & 117.0 \\
\hline H6 & HS-WE5-PM & 5.0 & 10.5 & 16.0 & 13.6 & 28.9 & 62.4 & 109.6 \\
\hline H7 & HS-ZM1-MF & 6.7 & 13.6 & 17.9 & 18.3 & 30.9 & 54.6 & 98.0 \\
\hline H8 & HS-ZM1-MPM & 5.8 & 13.8 & 15.4 & 14.4 & 31.5 & 53.1 & 97.5 \\
\hline \multirow[t]{2}{*}{$\mathrm{H} 9$} & HS-ZM1-PM & 4.5 & 12.4 & 15.0 & 11.9 & 27.6 & 55.6 & 115.9 \\
\hline & F-LSD $(0.05)$ & 2.1 & 2.2 & 1.4 & 4.0 & 7.02 & 8.97 & 11.04 \\
\hline
\end{tabular}

$\mathrm{WAP}=$ weeks after planting, NHS = non-heat-stress, HS = heat stress, WE3 = WE3128, WE5 = WE5323, ZM1 = ZM1523, MF = mineral fertilizers, $\mathrm{PM}=$ poultry manure, and MPM = complementary application of mineral fertilizer with poultry manure.

The longest number of days until tassel production was observed in the HS-WE5-MF interaction, which was statistically similar to the NHS-WE3-PM, NHS-WE3-MPM, and HS-ZM1-MF interactions (Table 12). The HS-ZM1-MF interaction was significantly higher than the other treatment interactions in the number of days until silk production. The number of days until tassel and silk production ranged from 53.7 to 83.8 days and 58.6 to 
92.4 days, respectively. The tassel silk interval ranged from 4.1 days in NHS-WE3-MPM to 12.1 days in HS-ZM1-MF. The NHS-WE5-PM interaction produced the highest dry biomass yield, which was significantly higher than the other treatment interactions, except for the NHS-WE3-MPM and NHS-WE3-PM interactions. HS-ZM1-PM gave the highest dry biomass yield under the heat-stress environment. A range of 66.5-200.0 $\mathrm{g} \mathrm{plant}^{-1}$ was obtained for dry biomass yield while the harvest index ranged from $8.2 \%$ in HS-WE3-MPM to $41 \%$ in NHS-ZM1-PM.

Table 12. Effect of heat stress, maize variety, and soil amendment on the reproductive and yield attributes of maize.

\begin{tabular}{ccccccc}
\hline SN & $\begin{array}{c}\text { Treatment } \\
\text { Interactions }\end{array}$ & DT & DS & TSI & DBY & HI \\
\hline N1 & NHS-WE3-MF & 77.1 & 85.8 & 8.7 & 115.0 & 31.0 \\
N2 & NHS-WE3-MPM & 82.9 & 87.0 & 4.1 & 193.8 & 31.0 \\
N3 & NHS-WE3-PM & 83.2 & 88.0 & 4.8 & 192.3 & 28.4 \\
N4 & NHS-WE5-MF & 70.7 & 80.4 & 9.8 & 98.5 & 28.7 \\
N5 & NHS-WE5-MPM & 72.5 & 82.3 & 9.8 & 185.7 & 34.4 \\
N6 & NHS-WE5-PM & 76.1 & 84.6 & 8.5 & 200.0 & 37.4 \\
N7 & NHS-ZM1-MF & 67.8 & 77.9 & 10.1 & 89.8 & 35.6 \\
N8 & NHS-ZM1-MPM & 67.3 & 75.6 & 8.3 & 175.8 & 40.5 \\
N9 & NHS-ZM1-PM & 71.0 & 80.3 & 9.3 & 182.8 & 41.0 \\
H1 & HS-WE3-MF & 53.7 & 58.6 & 6.3 & 88.9 & 12.3 \\
H2 & HS-WE3-MPM & 65.3 & 58.9 & 9.6 & 84.1 & 8.2 \\
H3 & HS-WE3-PM & 73.6 & 76.7 & 5.5 & 72.0 & 10.5 \\
H4 & HS-WE5-MF & 83.8 & 73.0 & 7.1 & 75.6 & 14.8 \\
H5 & HS-WE5-MPM & 65.9 & 74.2 & 8.3 & 103.5 & 15.1 \\
H6 & HS-WE5-PM & 67.6 & 78.3 & 10.8 & 81.7 & 20.0 \\
H7 & HS-ZM1-MF & 80.9 & 92.4 & 12.1 & 66.5 & 21.3 \\
H8 & HS-ZM1-MPM & 71.8 & 74.1 & 7.6 & 78.2 & 8.7 \\
H9 & HS-ZM1-PM & 67.1 & 70.9 & 9.7 & 109.2 & 13.8 \\
\multicolumn{7}{r}{ FHS $=$ non-heat-stress, HS = heat stress, WE3 = WE3128, WE5 = WE5323, ZM1 = ZM1523, MF = mineral } \\
fertilizers, PM = poultry manure, MPM = complementary application of mineral fertilizer with poultry manure, \\
DT = number of days until tasselling, DS = number of days until silking, TSI = tassel silk interval, DBY = dry \\
biomass yield (g plant ${ }^{-1}$ ), and HI = harvest index (\%). & & & &
\end{tabular}

The GGEbiplot explained 96.9\% ( $\mathrm{PC} 1=91.3 \%, \mathrm{PC} 2=5.6 \%$ ) of the variation among the treatment interactions. The average tester coordination view ranked the treatment interactions along the average tester axis (ATA) based on their mean performance and stability on the measured attributes. The ATA is represented by the single-arrow line, while the population mean is represented by the double-arrow line (Figure 7). Excluding $\mathrm{N} 7$, the remaining non-heat-stress treatments performed above the population mean. The ranking order was $\mathrm{N} 2>\mathrm{N} 6>\mathrm{N} 3>\mathrm{N} 9>\mathrm{N} 5>\mathrm{N} 8>\mathrm{N} 1>\mathrm{N} 4>$ population mean $>\mathrm{N} 7>$ $\mathrm{H} 5>\mathrm{H} 9>\mathrm{H} 6>\mathrm{H} 2>\mathrm{H} 4>\mathrm{H} 3>\mathrm{H} 8>\mathrm{H} 1>\mathrm{H} 7$. The leaf area at 10 WAP was the most discriminating and representative attribute and was followed by the dry biomass yield, stem diameter and plant height at 10 WAP (Figure 8). The remaining attributes clustered around the biplot origin. 


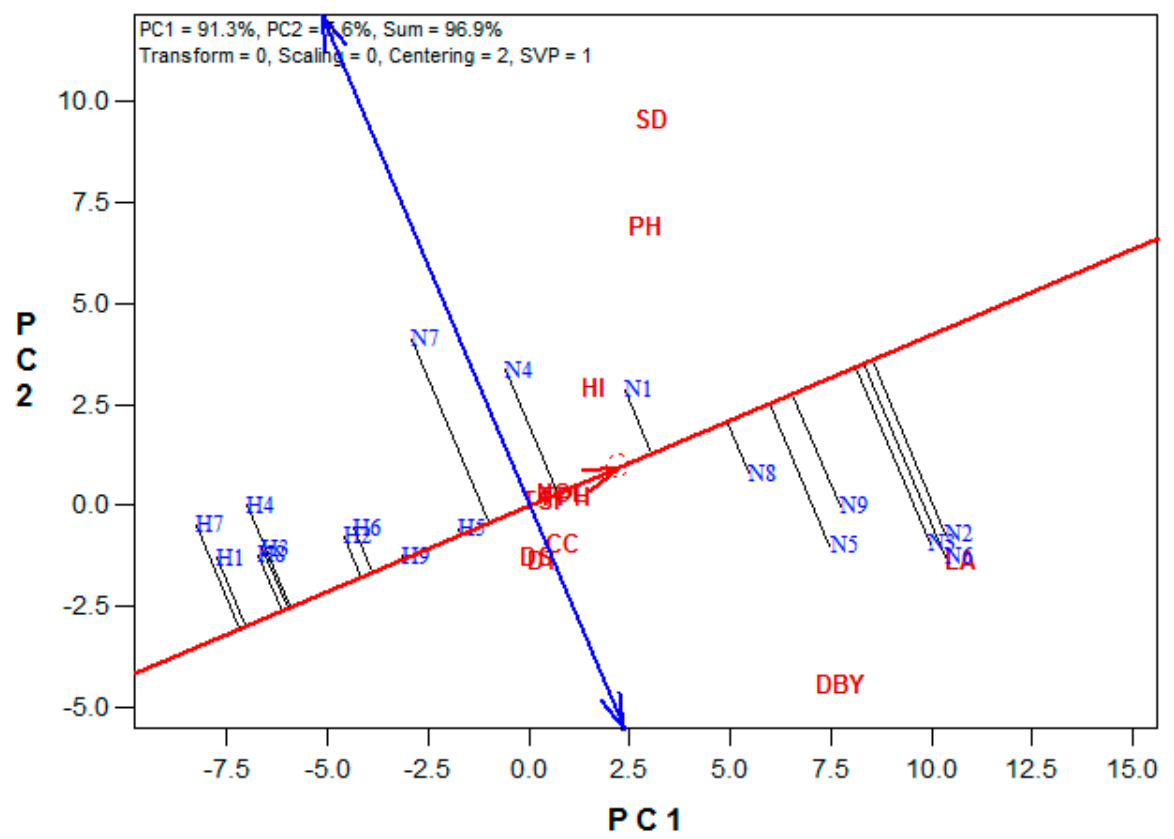

Figure 7. Mean performance and stability analysis of the treatment interactions.

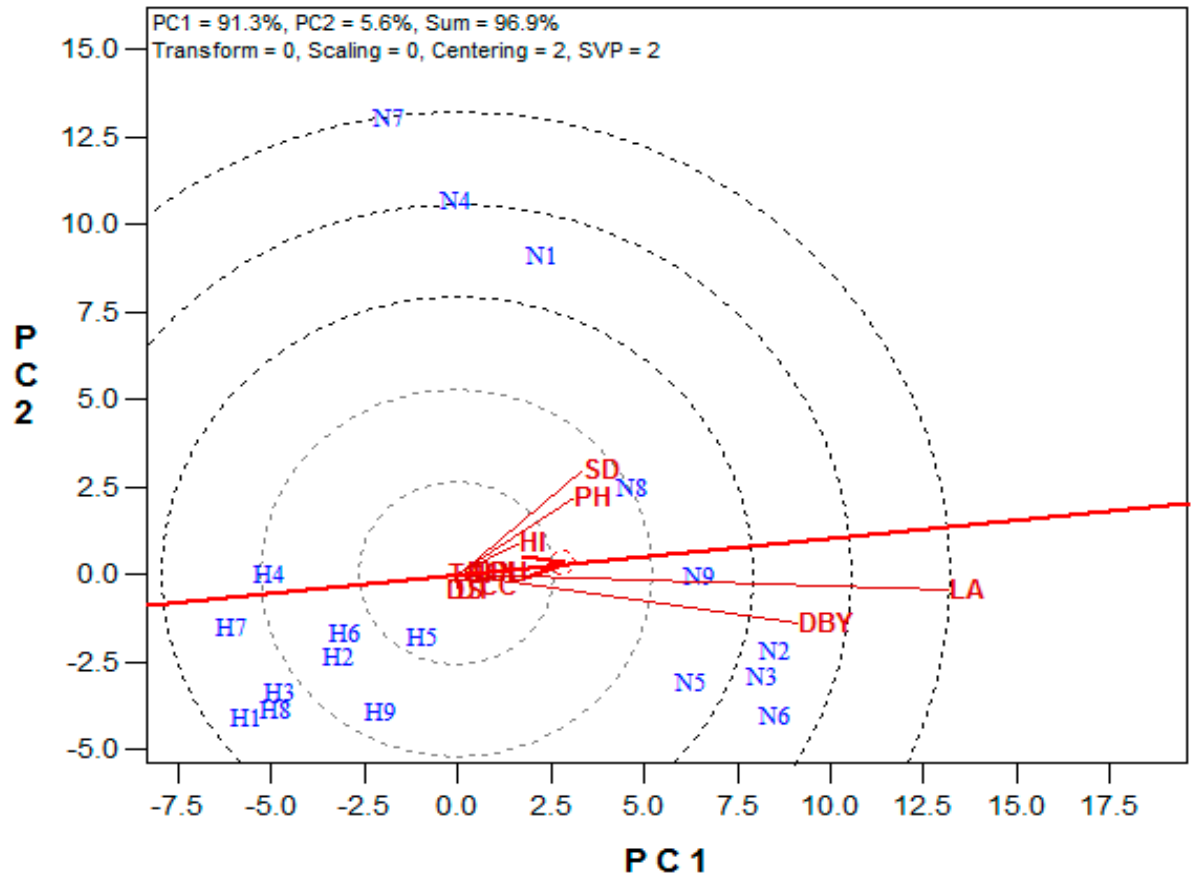

Figure 8. Discriminating and representative abilities of the studied attributes.

\section{Discussion}

\subsection{Temperature Variations between Growth Structures}

The significant differences in the growth and yield attributes observed between the growth structures validated their choice for this study, as the range of minimum and maximum temperatures obtained in the NHS environment favoured a non-heat-stress condition for the three maize varieties. Wahid et al. [45] described heat stress as a rise in temperature above a threshold that is sufficient to cause irreversible damage to plant growth and development. In a simulation study on the impact of extreme weather events in the maize producing areas of South Africa, Mangani, Tesfamariam, Engelbrecht, Bellocchi, Hassen, and Mangani [4] observed that high occurrence of days with temperatures 
above $30{ }^{\circ} \mathrm{C}$ will negatively impact maize growth and yield. Steven et al. [46] reported the optimum day temperature for maize to range from 25 to $32^{\circ} \mathrm{C}$. While maize plants can tolerate varying degrees of exposure to high temperatures, depending on the variety, prolonged exposure to temperatures above $35^{\circ} \mathrm{C}$ is unfavourable for growth [16]. Temperature beyond $40{ }^{\circ} \mathrm{C}$, particularly during flowering and grain filling, was reported to exert dire consequences on grain yields [20,47].

In this study, the HS environment witnessed nine incidences of average weekly temperatures of $\geq 35^{\circ} \mathrm{C}$ with three incidences occurring during the reproductive and grain filling phase in the first planting season. However, the average weekly temperature did not exceed $35^{\circ} \mathrm{C}$ in the NHS environment for both seasons. In the second planting season, the average weekly temperature of $\geq 35^{\circ} \mathrm{C}$ occurred 15 times with six incidences recorded during the reproductive and grain-filling phase. The high occurrence of temperatures above the optimum level for maize in the HS environment could account for the lower performances in maize growth and yield attributes obtained in it.

\subsection{Effects of Seasonal Variation in the Maize Growth Attributes and Dry Biomass Yield}

The observed significant difference across the two planting seasons was attributed to the difference in their recorded temperatures. The weather data obtained from the South African Weather Services for the period of the experiment showed a significant difference in the daily minimum and maximum temperatures. The heat stress occasioned by the observed higher temperatures in Season 2 may have exerted a negative impact on the maize growth and yield attributes measured. The effect of seasonal variation on maize growth was previously reported $[16,17,48,49]$. Tesfaye, Zaidi, Gbegbelegbe, Boeber, Getaneh, Seetharam, Erenstein, and Stirling [16] simulated maize yield under increasing temperatures in India and observed yield decline, as temperature increased in all their planting seasons. Belay and Adare [48] attributed a significant season effect in their maize study in Ethiopia to changes in climatic variables.

\subsection{Effects of Heat Stress on the Maize Growth Attributes and Dry Biomass Yield}

Heat stress reduced the growth capacity of maize in this study. The reduced number of leaves and leaf surface impaired the capacity of the stressed plants to convert light energy into biomass, needed for growth. Loss of leaf chlorophyll content further incapacitated the available leaves to function. The negative impact of heat stress on plant growth attributes was reported in other studies [17,50-52]. Dutta, Mohanty, and Tripathy [50] attributed the loss of leaf chlorophyll under heat stress to the deactivation of enzymes. Fahad et al. [53] opined that heat stress may cause severe damage to the proteins, disturb their synthesis, inactivate major enzymes, and damage membranes. Heat stress caused reduced activities of phosphoenolpyruvate carboxylase, Ribulose-1,5-bisphosphate carboxylase, nitrate reductase, and glutamine synthase in maize leaf, which shows suppressed leaf carbon and nitrogen metabolisms [52]. Reduction in the photosynthetic ability of the leaf can result from damage to chlorophyll pigments and a decline in leaf nitrogen contents [53].

Heat stress affected the plant's source and sink performances [54]. This assertion aligned with the observations in this study, where $\approx 38.5 \%$ of the source (leaf) was reduced due to heat stress. These reductions translated to a loss in accumulated dry biomass, as well as less allocation of photosynthates to the sink. In wheat, abnormal behaviour of source and sink as well as decreased photosynthesis occasioned by heat stress affected photosynthates partitioning [53]. Yield is a function of the amount of captured photosynthates, the conversion efficiency of the photosynthates into biomass, as well as partitioning of the biomass to the harvestable parts. In an event that the photosynthates are not partitioned to the harvestable parts, yield loss occurs. This manifests in a reduced harvest index. The reduction in the source capacity due to heat stress led to a low harvest index from the stressed plants compared to the non-stressed plants. Edreira and Otegui [17] reported a reduced harvest index when maize plants were exposed to heat stress. Mangani, 
Tesfamariam, Engelbrecht, Bellocchi, Hassen, and Mangani [4] projected yield loss in maize producing areas of South Africa experiencing higher temperatures.

\subsection{Effects of Variety on the Maize Growth Attributes and Dry Biomass Yield}

Yield stability is often targeted in breeding programs [55]. This is to mitigate yield loss in the event of a sudden weather change. Evaluating breeding lines under contrasting environments was used to identify superior genotypes [56-58]. To develop heat-tolerant lines, Ehlers and Hall [59] suggested subjecting the breeding lines to heat stress before selection based on their performance. A plant's ability to maintain minimal damage to its source capacity, with sustained biosynthesis of protective compounds is an indication of heat tolerance [21]. Similarly, Tiwari and Yadav [60] identified a high number of leaves per plant as essential in heat tolerance. Different genetic expressions in growth and yield attributes were reported in maize [48,61-64].

In this study, the significant differences observed in the three maize varieties are attributed to their genetic differences. ZM1523 and WE5323 performed better than WE3128 in the morphological attributes studied, excluding the final plant height at harvest. WE3128 exhibited a slow growth rate that resulted in delayed onset of the reproductive phase and probably reduced the grain filling phase. This may explain the low harvest index and high dry biomass obtained from this variety. On the other hand, ZM1523 and WE5323 attained the reproductive phase earlier, which may have enhanced their grain-filling periods. Though ZM1523 and WE5323 were statistically similar in harvest index, ZM1523 was better at producing the highest harvest index from the lowest dry biomass yield. From the $114.9 \mathrm{~g} \mathrm{plant}^{-1}$ biological yield accumulated by ZM1523, $28.8 \mathrm{~g} \mathrm{plant}^{-1}$ was partitioned to economic yield, while WE5323 allocated $26 \mathrm{~g}$ of its $121.9 \mathrm{~g} \mathrm{plant}^{-1}$ biological yield to the economic yield. Lunduka, Mateva, Magorokosho, and Manjeru [64] reported that the choice of maize variety used by farmers in Eastern Zimbabwe accounted for about $247 \mathrm{~kg}$ acre $^{-1}$ difference in their yield.

\subsection{Effects of Soil Amendment on the Maize Growth Attributes and Dry Biomass Yield}

Marginal land cultivation threatens sustainable crop production and livelihoods for smallholder farmers. The food security situation is further threatened when an extreme weather event occurs in marginal cultivated land. Therefore, sustainable crop production requires constant replenishment of lost nutrients from the soil. Hence, an adequate supply of nutrients is needed for better crop growth and development [65,66]. Bhatt, et al. [67] observed that maize productivity was influenced by the combination of different sources of organic and inorganic soil amendments. Studies have shown the benefits of soil amendments to crop yield, as well as improvement of soil properties [27-30]. Tahir et al. [68] suggested the alleviation of plant stress through nutrient management.

The main effects of soil amendment showed that the plants amended with MF were taller than those amended with MPM and PM. However, the leaf chlorophyll contents of the MPM and PM amendments were higher than the MF amendment. The better chlorophyll contents of MPM and PM amendments enhanced their photosynthetic capacity, which resulted in a better dry biomass accumulation and partitioning to the economic part. Dry biomass accumulation followed the order of PM $>$ MPM $>$ MF. A similar trend in dry matter accumulation was reported by Geng et al. [69]. Waraich et al. [70] reported more biomass production per unit of transpired water from a well-nourished plant, compared to poorly nourished plants, as utilization of absorbed light energy in electron transport was higher in well-nourished plants. Waraich, Ahmad, Halim, and Aziz [70] opined that adequate nutrition is essential for the integrity of plant structure and key physiological processes. The better performance of the PM and MPM observed in this study aligned with other reports of soil amendment on maize plants $[31,48,67]$. However, this study is unique as it evaluated these soil amendments in a heat-stress environment. 


\subsection{Effects of Soil Type on the Maize Growth Attributes and Dry Biomass Yield}

In this study, the inherent differences between the two soil properties contributed to observed variations in the measured maize attributes. Soil provides anchorage as well as stores nutrients and water needed for plant growth. The degree to which soil performs these functions depends on its properties. Widowati, Sutoyo, Karamina, and Fikrinda [30] observed that the physical properties of soils influenced maize plants grown on them. Fang and Su [71] reported that soil properties influenced maize nitrogen uptake and yield. They attributed this influence to increased organic matter concentration and silt/clay content. Clay loam soil promoted nitrogen uptake than loamy sand soil [72]. Akinyele and Adigun [73] in their study, Soil Texture and the Phenotypic Expression of Maize, observed significant variation in leaf length, leaf width, plant height, and stem diameter of maize due to soil types. Olayiwola and Oyediran [74] reported a similarly significant effect of soil type on maize plant height and number of leaves. These reports aligned with the findings in this study, where significant variations were observed in the number of leaves, leaf area, leaf chlorophyll content, plant height, and stem diameter.

Moral and Rebollo [75] characterized soil fertility using the Rasch Model and concluded that particle-size distribution, electrical conductivity, cation exchange capacity, $\mathrm{pH}$, organic matter, and the primary nutrients $(\mathrm{N}, \mathrm{P}$, and $\mathrm{K})$ are the most influential variables on soil fertility. They maintained that soil texture and $\mathrm{pH}$ influenced the extent to which nutrients are available to plants. Clayey and organic soils hold nutrients and water more compared to sandy soils, while neutral soil $\mathrm{pH}$ promotes nutrient availability and plant root growth [76]. In this study, higher clay content and $\mathrm{pH}$ closer to neutral were observed in the SCL soil. Hence, these properties may have influenced its better growth, which resulted in a higher dry biomass accumulation and subsequent harvest index over the LS soil.

\subsection{The Interaction of Heat Stress, Maize Variety, Soil Amendment, and Soil Type on the Maize Growth and Yield Attributes}

Plant growth and development are a function of the plant's genetic base and the environment for expressing the gene [58]. The environment is influenced by the presence or absence of abiotic stress factors. The absence of abiotic stress promotes the full actualization of a plant's potential, while abiotic stress limits the plant's potential. Plants often adopt different mechanisms to overcome stress, which may cause yield loss. Heat stress is one of the major abiotic stresses that limit maize yield [13-16]. Belay and Adare [48] opined that plants can perform optimally if proper management practices are implemented.

In this study, different management options were tested to understand their contributions to ameliorating the effect of heat stress on maize plants. Significant variations in growth and yield attributes were observed within and among the maize varieties when grown under different conditions. The varietal variation observed in this study aligned with earlier reports on maize [48,58,61-64].

A general trend of reduced performance in the maize growth and yield attributes was observed in the HS environment compared to the NHS environment in this study. This was attributed to heat stress resulting from the above optimum high temperature recorded in the HS environment. Steven, Brandner, and Salvucci [46] noted that as a $\mathrm{C}_{4}$ plant, maize benefits from high temperature; however, a temperature rise beyond $32{ }^{\circ} \mathrm{C}$ impaired growth and development in maize. There is agreement among scientists that the South African temperature, as well as global temperature, will rise with climate change [6-11]. While this temperature rise may not be averted, it can be managed. Proper plant nutrition is one of the management options proposed for ameliorating heat stress in plants. Waraich, Ahmad, Halim, and Aziz [70] recognized the vital role played by plant nutrients in improving heat stress tolerance.

The ranking of the treatment interactions revealed that the top four ranked treatment interactions in the NHS and HS environments were amended with either MPM or $\mathrm{PM}$, while the least ranked treatment interactions in both environments contained MF 
amendment. Bhatt, Bhattachan, Marahatta, and Jagat [67] observed a similar improvement in maize productivity due to the use of the organic manure amendment. Other studies reported the beneficial effect of PM on crop productivity, as well as improvement in soil properties [27-30]. Ali and Anjum [65] reported that an adequate supply of nutrients was important for better crop growth and development. Waraich, Ahmad, Halim, and Aziz [70] attributed more biomass production per unit of transpired water in a well-nourished plant, as opposed to poorly nourished plants, to better utilization of absorbed light energy in electron transport by the well-nourished plant.

To maximize maize production, the selection of appropriate agronomic practices and the use of improved varieties should be considered [48]. This is pertinent in the event of extreme weather events like heat stress. In this study, the selection of soil amendment and maize variety produced different growth and yield performances under the two contrasting environments. This observation indicates a likely shift from the current agronomic practices used in maize production, considering the future impact of rising temperatures. Hence, it is imperative to conserve and maintain the genetic biodiversity necessary for future breeding programs. Among the maize studied attributes in this study, leaf area, dry biomass yield, plant height, and stem diameter were the most discriminating and representative attributes due to their vector length and angle to the ATA (Figure 8). The attributes that are both discriminating, and representative are good attributes for selecting generally adapted genotypes [77]. Yan et al. [78] reported that the attributes that are located close to the biplot origin offer little or no information about the variation in a population.

In the NHS environment, the best performance obtained from the variety WE3128 was under the MPM amendment, while the PM amendment gave the best performance for varieties WE5323 and ZM1523. These treatment interactions produced the highest dry biomass yield, stem diameter, harvest index, and leaf area for each of the three maize varieties. Under the HS environment, these treatment interactions ranked first for each of the three maize varieties, except for WE5323, which obtained its best performance from the MPM amendment.

Understanding the climatic and edaphic requirements of newly bred maize varieties will improve their harvest index. The harvest index represented the physiological efficiency and ability of a crop to convert the total dry matter into economic yield [79]. Ion, Dicu, Dumbravă, Temocico, Alecu, Băşa, and State [61] reported a higher harvest index for maize under more favourable soil and climatic conditions than under less favourable conditions. They concluded that maize variety, as well as agronomic practices, influenced the maize harvest index. The report corroborated our observations on the maize harvest index in this study, where the NHS environment produced more harvest index than the HS environment. Better resource use efficiencies will substantially improve the productivity and sustainability of low-input agroecosystems, and importantly, under high input agroecosystems, will reduce the environmental impacts of intensive fertilization [80].

\section{Conclusions}

Significant variations in growth and yield attributes were observed within and among the maize varieties when grown under different conditions. Heat stress exerted a depressive effect on the maize plant growth and yield attributes. Heat stress reduced the maize leaf chlorophyll content, leaf area, number of leaves, plant height, stem diameter, dry biomass yield, and harvest index by 35\%, 36\%, 35\%, 41\%, 59\%, and 78\%, respectively. The sandy clay loam soil provided a better maize growth condition than loamy sandy soil. The organic soil amendment improved maize growth attributes over the mineral fertilizer. The ranking of the treatment interactions revealed that the top four ranked treatment interactions in the NHS and HS environments were amended with either MPM or PM, while the least ranked treatment interactions in both environments contained MF amendment. The MPM amendment gave the best performance for the variety WE3128, while the PM amendment produced the best performances for varieties WE5323 and ZM1523 in the NHS and HS environments. The ranking of the studied attributes identified leaf area, dry biomass yield, 
stem diameter, and plant height as the most discriminating and representative attributes. These attributes should be considered in maize development projects for heat-stress prone areas. The selection of appropriate maize variety and accompanying soil amendment should be integrated into the food security strategy as the factors influenced maize growth and yield under heat- and non-heat stress conditions.

Author Contributions: Conceptualization, U.P.C., F.R.K. and S.M.; methodology, U.P.C., F.R.K. and S.M.; formal analysis, U.P.C.; investigation, U.P.C.; data curation, U.P.C.; writing-original draft preparation, U.P.C.; writing-review and editing, U.P.C., F.R.K. and S.M.; and supervision, F.R.K. and S.M. All authors have read and agreed to the published version of the manuscript.

Funding: This research received no external funding.

Institutional Review Board Statement: Not applicable.

Informed Consent Statement: Not applicable.

Data Availability Statement: The data presented in this study are available on request from the corresponding author.

Acknowledgments: Authors fully acknowledge the financial supports of the North-West University as bursaries for U.P.C.

Conflicts of Interest: The authors declare no conflict of interest.

\section{References}

1. Ramirez-Cabral, N.Y.Z.; Kumar, L.; Shabani, F. Global alterations in areas of suitability for maize production from climate change and using a mechanistic species distribution model (CLIMEX). Sci. Rep. 2017, 7, 5910. [CrossRef]

2. FAO. FAOSTAT Database. 2018. Available online: https://www.fao.org/faostat/en/\#data (accessed on 12 July 2020).

3. DAFF. Trends in the Agricultural Sector 2017; Department of Agriculture, Forestry and Fisheries: Pretoria, South Africa, 2017 ; p. 79.

4. Mangani, R.; Tesfamariam, E.H.; Engelbrecht, C.J.; Bellocchi, G.; Hassen, A.; Mangani, T. Potential impacts of extreme weather events in main maize (Zea mays L.) producing areas of South Africa under rainfed conditions. Reg. Environ. Chang. 2019, 19, 1441-1452. [CrossRef]

5. DAFF. A Profile of the South African Maize Market Value Chain 2016; Department of Agriculture, Forestry and Fisheries: Pretoria, South Africa, 2016; p. 45.

6. Jury, M.R. Climate trends across South Africa since 1980. Water S. Afr. 2018, 44, 297-307. [CrossRef]

7. Landman, W.A.; Engelbrecht, F.; Hewitson, B.; Malherbe, J.; Van der Merwe, J. Towards bridging the gap between climate change projections and maize producers in South Africa. Theor. Appl. Climatol. 2018, 132, 1153-1163. [CrossRef]

8. van Wilgen, N.J.; Goodall, V.; Holness, S.; Chown, S.L.; McGeoch, M.A. Rising temperatures and changing rainfall patterns in South Africa's national parks. Int. J. Climatol. 2015, 36, 706-721. [CrossRef]

9. IPCC. Climate Change 2014: Synthesis Report. Contribution of Working Groups I, II and III to the Fifth Assessment Report of the Intergovernmental Panel on Climate Change; IPCC: Geneva, Switzerland, 2014; p. 151.

10. Kent, C.; Chadwick, R.; Rowell, D.P. Understanding uncertainties in future projections of seasonal tropical precipitation. J. Clim. 2015, 28, 4390-4413. [CrossRef]

11. Gabaldón-Leal, C.; Webber, H.; Otegui, M.E.; Slafer, G.A.; Ordóñez, R.A.; Gaiser, T.; Lorite, I.J.; Ruiz-Ramos, M.; Ewert, F. Modelling the impact of heat stress on maize yield formation. Field Crop. Res. 2016, 198, 226-237. [CrossRef]

12. Mangani, R.; Tesfamariam, E.; Bellocchi, G.; Hassen, A. Modelled impacts of extreme heat and drought on maize yield in South Africa. Crop. Pasture Sci. 2018, 69, 703-716. [CrossRef]

13. Alam, M.A.; Seetharam, K.; Zaidi, P.H.; Dinesh, A.; Vinayan, M.T.; Nath, U.K. Dissecting heat stress tolerance in tropical maize (Zea mays L.). Field Crop. Res. 2017, 204, 110-119. [CrossRef]

14. Lizaso, J.I.; Ruiz-Ramos, M.; Rodríguez, L.; Gabaldon-Leal, C.; Oliveira, J.A.; Lorite, I.J.; Sánchez, D.; García, E.; Rodríguez, A. Impact of high temperatures in maize: Phenology and yield components. Field Crop. Res. 2018, 216, 129-140. [CrossRef]

15. Wu, W.; Ma, B.L.; Whalen, J.K. Enhancing rapeseed tolerance to heat and drought stresses in a changing climate: Perspectives for stress adaptation from root system architecture. In Advances in Agronomy; Sparks, D.L., Ed.; Academic Press: Cambridge, MA, USA, 2018; p. 157.

16. Tesfaye, K.; Zaidi, P.; Gbegbelegbe, S.; Boeber, C.; Getaneh, F.; Seetharam, K.; Erenstein, O.; Stirling, C. Climate change impacts and potential benefits of heat-tolerant maize in South Asia. Theor. Appl. Climatol. 2017, 130, 959-970. [CrossRef]

17. Edreira, J.I.R.; Otegui, M.E. Heat stress in temperate and tropical maize hybrids: Differences in crop growth, biomass partitioning and reserves use. Field Crop. Res. 2012, 130, 87-98. [CrossRef] 
18. Cairns, J.E.; Sonder, K.; Zaidi, P.H.; Verhulst, N.; Mahuku, G.; Babu, R.; Nair, S.; Das, B.; Govaerts, B.; Vinayan, M.T. Maize production in a changing climate: Impacts, adaptation, and mitigation strategies. In Advances in Agronomy; Elsevier: Amsterdam, The Netherlands, 2012; Volume 114, pp. 1-58.

19. Mayer, L.I.; Rattalino Edreira, J.I.; Maddonni, G.A. Oil yield components of maize crops exposed to heat stress during early and late grain-filling stages. Crop Sci. 2014, 54, 2236-2250. [CrossRef]

20. Rezaei, E.E.; Webber, H.; Gaiser, T.; Naab, J.; Ewert, F. Heat stress in cereals: Mechanisms and modelling. Eur. J. Agron. 2015, 64, 98-113. [CrossRef]

21. Bita, C.; Gerats, T. Plant tolerance to high temperature in a changing environment: Scientific fundamentals and production of heat stress-tolerant crops. Front. Plant Sci. 2013, 4, 273. [CrossRef] [PubMed]

22. Libanda, B.; Bwalya, K.; Nkolola, N.B.; Chilekana, N. Quantifying long-term variability of precipitation and temperature over Zambia. J. Atmos. Sol. Terr. Phys. 2020, 198, 105201. [CrossRef]

23. Weepener, H.L.; Engelbrecht, C.J.; Carstens, J. Sensitivity of Crop Suitability in South Africa to Climate Change; ARC-ISCW report no: GW/A/2014/29; ARC-Institute for Soil, Climate and Water: Pretoria, South Africa, 2014.

24. Haarhoff, S.J.; Kotzé, T.N.; Swanepoel, P.A. A prospectus for sustainability of rainfed maize production systems in South Africa. Crop. Sci. 2020, 60, 14-28. [CrossRef]

25. Steward, P.R.; Dougill, A.J.; Thierfelder, C.; Pittelkow, C.M.; Stringer, L.C.; Kudzala, M.; Shackelford, G.E. The adaptive capacity of maize-based conservation agriculture systems to climate stress in tropical and subtropical environments: A meta-regression of yields. Agric. Ecosyst. Environ. 2018, 251, 194-202. [CrossRef]

26. Kutu, F.R. Effect of conservation agriculture management practices on maize productivity and selected soil quality indices under South Africa dryland conditions. Afr. J. Agric. Res. 2012, 7, 3839-3846. [CrossRef]

27. Yagi, R.; Quadros, T.C.F.; Martins, B.H.; Andrade, D.S. Maize yields and carbon pools in response to poultry litter, rock phosphate and P-solubilizing microorganisms. Sci. Agric. 2020, 77, e20180141. [CrossRef]

28. Kandil, E.E.; Abdelsalam, N.R.; Mansour, M.A.; Ali, H.M.; Siddiqui, M.H. Potentials of organic manure and potassium forms on maize (Zea mays L.) growth and production. Sci. Rep. 2020, 10, 1-11. [CrossRef] [PubMed]

29. Mokgolo, M.J.; Mzezewa, J.; Odhiambo, J.J. Poultry and cattle manure effects on sunflower performance, grain yield and selected soil properties in Limpopo Province, South Africa. S. Afr. J. Sci. 2019, 115, 1-7. [CrossRef]

30. Widowati, W.; Sutoyo, S.; Karamina, H.; Fikrinda, W. Soil amendment impact to soil organic matter and physical properties on the three soil types after second corn cultivation. AIMS Agric. Food 2020, 5, 150-168. [CrossRef]

31. Materechera, S.A. Utilization and management practices of animal manure for replenishing soil fertility among smallscale crop farmers in semi-arid farming districts of the North West Province, South Africa. Nutr. Cycl. Agroecosyst. 2010, 87, 415-428. [CrossRef]

32. Findlater, K.M.; Kandlikar, M.; Satterfield, T. Misunderstanding conservation agriculture: Challenges in promoting, monitoring and evaluating sustainable farming. Environ. Sci. Policy 2019, 100, 47-54. [CrossRef]

33. Zhao, C.; Piao, S.; Huang, Y.; Wang, X.; Ciais, P.; Huang, M.; Zeng, Z.; Peng, S. Field warming experiments shed light on the wheat yield response to temperature in China. Nat. Commun. 2016, 7, 1-8. [CrossRef] [PubMed]

34. Greyling, J.C.; Pardey, P.G. Measuring maize in South Africa: The shifting structure of production during the twentieth century, 1904-2015. Agrekon 2019, 58, 21-41. [CrossRef]

35. Zhao, C.; Liu, B.; Piao, S.; Wang, X.; Lobell, D.B.; Huang, Y.; Huang, M.; Yao, Y.; Bassu, S.; Ciais, P. Temperature increase reduces global yields of major crops in four independent estimates. Proc. Natl. Acad. Sci. USA 2017, 114, 9326-9331. [CrossRef]

36. NWPG. North West Environment Outlook Report 2018; North West Provincial Government: Mafikeng, South Africa, 2018 ; pp. 1-52.

37. Bouyoucos, J. A rapid determination of soil texture. J. Agric. Sci. 1963, 23, 456-459.

38. Bremner, J.M.; Mulvaney, C.S. Nitrogen Total: Methods of Soil Analysis, Part 2: Chemical and Microbiological Properties; American Society of Agronomy: Madison, WI, USA, 1982; pp. 595-624.

39. Nelson, D.W.; Sommers, L.E. Total carbon, organic carbon, and organic matter. In Methods of Soil Analysis Part 3-Chemical Methods; John Wiley \& Sons: Hoboken, NJ, USA, 1996; pp. 961-1010.

40. Bray, R.H.; Kurtz, L.T. Determination of total, organic, and available forms of phosphorus in soils. Soil Sci. 1945, 59, 39-46. [CrossRef]

41. Page, A.L.; Miller, R.H.; Keeney, D.R. Methods of Soil Analysis, Part 2: Chemical and Microbiological Properties, 2nd ed.; American Society of Agronomy: Madison, WI, USA, 1982.

42. Soil Classification Working Group. Soil Classification: A Taxonomic System for South Africa, 2nd ed.; Department of Agricultural Development: Pretoria, South Africa, 1991; p. 257.

43. Mokhtarpour, H.; Teh, C.B.; Saleh, G.; Selamat, A.B.; Asadi, M.E.; Kamkar, B. Non-destructive estimation of maize leaf area, fresh weight, and dry weight using leaf length and leaf width. Commun. Biometry Crop. Sci. 2010, 5, 19-26.

44. Yan, W.; Tinker, N.A. Biplot analysis of multi-environment trial data: Principles and applications. Can. J. Plant Sci. 2006, 86, 623-645. [CrossRef]

45. Wahid, A.; Gelani, S.; Ashraf, M.; Foolad, M.R. Heat tolerance in plants: An overview. Environ. Exp. Bot. 2007, 61, 199-223. [CrossRef]

46. Steven, J.; Brandner, C.; Salvucci, M. Sensitivity of photosynthesis in a C4 maize plant to heat stress. Plant Physiol. 2002, 129, 1773-1780. [CrossRef] 
47. Noor, J.J.; Vinayan, M.T.; Umar, S.; Devi, P.; Iqbal, M.; Seetharam, K.; Zaidi, P.H. Morpho-physiological traits associated with heat stress tolerance in tropical maize (Zea mays L.) at reproductive stage. Aust. J. Crop. Sci. 2019, 13, 536-545. [CrossRef]

48. Belay, M.; Adare, K. Response of growth, yield components, and yield of hybrid maize (Zea mays L.) varieties to newly introduced blended NPS and N fertilizer rates at Haramaya, Eastern Ethiopia. Cogent Food Agric. 2020, 6, 1771115. [CrossRef]

49. Uba, C.U.; Agbo, C.U.; Chukwudi, U.P.; Efusie, A.A.; Muojiama, S.O. Field evaluation of yield and yield component traits of breeding lines of maize over two seasons in derived Savannah agro-ecology. Not. Sci. Biol. 2018, 10. [CrossRef]

50. Dutta, S.; Mohanty, S.; Tripathy, B.C. Role of temperature stress on chloroplast biogenesis and protein import in pea. Plant Physiol. 2009, 150, 1050-1061. [CrossRef] [PubMed]

51. Springate, D.A.; Kover, P.X. Plant responses to elevated temperatures: A field study on phenological sensitivity and fitness responses to simulated climate warming. Glob. Chang. Biol. 2014, 20, 456-465. [CrossRef] [PubMed]

52. Yang, H.; Gu, X.-T.; Ding, M.-Q.; Lu, W.-P.; Lu, D.-L. Weakened carbon and nitrogen metabolisms under post-silking heat stress reduce the yield and dry matter accumulation in waxy maize. J. Integr. Agric. 2020, 19, 78-88. [CrossRef]

53. Fahad, S.; Bajwa, A.A.; Nazir, U.; Anjum, S.A.; Farooq, A.; Zohaib, A.; Sadia, S.; Nasim, W.; Adkins, S.; Saud, S. Crop production under drought and heat stress: Plant responses and management options. Front. Plant Sci. 2017, 8, 1147. [CrossRef] [PubMed]

54. Taiz, L.; Zeiger, E. Plant Physiology, 6th ed.; Sinauer Associates: Sunderland, MA, USA, 2014; Volume 1, p. 137.

55. Cairns, J.E.; Prasanna, B.M. Developing and deploying climate-resilient maize varieties in the developing world. Curr. Opin. Plant Biol. 2018, 45, 226-230. [CrossRef] [PubMed]

56. Rezende, W.S.; Beyene, Y.; Mugo, S.; Ndou, E.; Gowda, M.; Sserumaga, J.P.; Asea, G.; Ngolinda, I.; Jumbo, M.; Oikeh, S.O.; et al. Performance and yield stability of maize hybrids in stress-prone environments in eastern Africa. Crop J. 2020, 8, 107-118. [CrossRef]

57. Mushayi, M.; Shimelis, H.; Derera, J.; Shayanowako, A.I.T.; Mathew, I. Multi-environmental evaluation of maize hybrids developed from tropical and temperate lines. Euphytica 2020, 216, 84-93. [CrossRef]

58. Inyang, P.; Ene, C.O.; Emmanuel, A.; Chukwudi, U.P.; Ikeogu, U.N. Environmental impact and genetic expressions of new drought-tolerant maize genotypes in derived savannah agro-ecology. Not. Sci. Biol. 2021, 13, 10691. [CrossRef]

59. Ehlers, J.D.; Hall, A.E. Heat tolerance of contrasting cowpea lines in short and long days. Field Crop. Res. 1998, 55, 11-21. [CrossRef]

60. Tiwari, Y.K.; Yadav, S.K. High temperature stress tolerance in maize (Zea mays L.): Physiological and molecular mechanisms. J. Plant Biol. 2019, 62, 93-102. [CrossRef]

61. Ion, V.; Dicu, G.; Dumbravă, M.; Temocico, G.; Alecu, I.N.; Băşa, A.G.; State, D. Harvest index at maize in different growing conditions. Rom. Biotechnol. Lett. 2015, 20, 10951.

62. Hatfield, J.L. Increased temperatures have dramatic effects on growth and grain yield of three maize hybrids. Agric. Environ. Lett. 2016, 1, 1-5. [CrossRef]

63. Yusuf, M.J.; Musa, U.; Ifeoluwa, A.O. Evaluation of maize varieties under varying fertilizer application rates in Owode-Egba Area of Ogun State Nigeria. J. Agric. Vet. Sci. 2019, 12, 25-32. [CrossRef]

64. Lunduka, R.W.; Mateva, K.I.; Magorokosho, C.; Manjeru, P. Impact of adoption of drought-tolerant maize varieties on total maize production in South Eastern Zimbabwe. Clim. Dev. 2019, 11, 35-46. [CrossRef]

65. Ali, N.; Anjum, M.M. Effect of different nitrogen rates on growth, yield and quality of maize. Middle East J. Agric. Res. 2017, 6, $107-112$.

66. Agbo, C.U.; Chukwudi, P.U.; Ogbu, A.N. Effects of rates and frequency of application of organic manure on growth, yield and biochemical composition of Solanum melongena L. (cv. 'Ngwa local') fruits. J. Anim. Plant Sci. 2012, 14, $1952-1960$.

67. Bhatt, K.R.; Bhattachan, B.K.; Marahatta, S.; Jagat, B.A. Growth and profitability of Maize (Zea mays L.) Under Sole and Combined Applications of Different Organic and Inorganic Nutrient Management at Rampur, Chitwan, Nepal. J. Biol. Today's World 2020, 9, 1-6.

68. Tahir, M.A.; Aziz, T.; Rahmatullah. Silicon-induced growth and yield enhancement in two wheat genotypes differing in salinity tolerance. Commun. Soil Sci. Plant Anal. 2011, 42, 395-407. [CrossRef]

69. Geng, Y.; Cao, G.; Wang, L.; Wang, S. Effects of equal chemical fertilizer substitutions with organic manure on yield, dry matter, and nitrogen uptake of spring maize and soil nitrogen distribution. PLoS ONE 2019, 14, e0219512. [CrossRef] [PubMed]

70. Waraich, E.; Ahmad, R.; Halim, A.; Aziz, T. Alleviation of temperature stress by nutrient management in crop plants: A review. J. Soil Sci. Plant Nutr. 2012, 12, 221-244. [CrossRef]

71. Fang, J.; Su, Y. Effects of soils and irrigation volume on maize yield, irrigation water productivity, and nitrogen uptake. Sci. Rep. 2019, 9, 7740. [CrossRef]

72. Van Es, H.M.; Yang, C.L.; Geohring, L.D. Maize nitrogen response as affected by soil type and drainage variability. Precis. Agric. 2005, 6, 281-295. [CrossRef]

73. Akinyele, B.; Adigun, A. Soil texture and the phenotypic expression of maize (Zea mays L.). Res. J. Bot. 2006, 1, 139-143. [CrossRef]

74. Olayiwola, A.O.; Oyediran, G.O. Effect of Soil Types and Phosphorus Fertilizer Interaction on the Growth and Yield of Maize (Zea mays. L). Int. J. Appl. Agric. Apic. Res. 2012, 8, 82-90.

75. Moral, F.J.; Rebollo, F.J. Characterization of soil fertility using the Rasch model. J. Soil Sci. Plant Nutr. 2017, 17, 486-498. [CrossRef]

76. Baiyeri, K.P.; Chukwudi, U.P.; Chizaram, C.A.; Aneke, N. Maximizing rice husk waste for Daucus carota production. Int. J. Recycl. Org. Waste Agric. 2019, 8, 399-406. [CrossRef] 
77. Yan, W. GGE Biplot vs. AMMI graphs for genotype-by-environment data analysis. J. Indian Soc. Agric. Stat. 2011, 65, 181-193.

78. Yan, W.; Kang, M.S.; Ma, B.; Woods, S.; Cornelius, P.L. GGE Biplot vs. AMMI Analysis of Genotype-by-Environment Data. Crop Sci. 2007, 47, 643-653. [CrossRef]

79. Sharifi, R.S.; Sedghi, M.; Gholipouri, A. Effect of population density on yield and yield attributes of maize hybrids. Res. J. Biol. Sci. 2009, 4, 375-379.

80. Davies, W.J.; Zhang, J.; Yang, J.; Dodd, I.C. Novel crop science to improve yield and resource use efficiency in water-limited agriculture. J. Agric. Sci. 2011, 149, 123-131. [CrossRef] 